\title{
Middle Ordovician acritarchs and problematic organic-walled microfossils from the Saq-Hanadir transitional beds in the QSIM-801 well, Saudi Arabia
}

\author{
Alain Le Hérissé ${ }^{a}$, Marco Vecoli ${ }^{b},{ }^{*}$, Claudia Guidat ${ }^{\mathrm{a}}$, Fabrice Not $^{\mathrm{c}}$, Pierre Breuer ${ }^{\mathrm{b}}$, \\ Charles Wellman ${ }^{\mathrm{d}}$, Philippe Steemans ${ }^{\mathrm{e}}$ \\ ${ }^{a}$ Université de Brest, UMR 6538 CNRS « Domaines océaniques », IUEM, CS 93837, rue Dumont D’Urville, 29280 Plouzané, France \\ ${ }^{\mathrm{b}}$ Biostratigraphy Group, Geological Technical Services, Saudi Aramco, 31311 Dhahran, Saudi Arabia \\ c Plankton Group, UMR 7144, Station Biologique de Roscoff, CNRS \& UPMC, place Georges-Teissier, CS 90074, 29688 Roscoff cedex, France \\ ${ }^{\mathrm{d}}$ Department of Animal and Plant Sciences, University of Sheffield, Alfred Denny Building, Western Bank, S10 2TN Sheffield, UK \\ ${ }^{\mathrm{e}}$ Laboratory of Palaeobiogeology, Palaeobotany, Palaeopalynology, Liège University, 4000 Liège, Belgium
}

\begin{abstract}
Core samples from the QSIM-801 water well, drilled in central Saudi Arabia, cover a 93-foot interval spanning the transition between the Sajir Member of the Saq Formation, that consists mainly of sandstones of tidal sand flat environments, and the Hanadir Member of the Qasim Formation, characterized by argillaceous graptolitic mudstones, corresponding to a tidal delta front. The samples contain abundant, exceptionally well-preserved and diverse palynomorphs, which include cryptospores, acritarchs and chitinozoans, other problematic organic-walled microfossils as well as other organic particles such as cuticle-like fragments. The studied interval is biostratigraphically well constrained by the presence of chitinozoans of the formosa and pissotensis Zones of late-early to late Darriwilian age (Middle Ordovician) in the uppermost Saq Formation and Hanadir Member. The biostratigraphic age of the Sajir Member considered to span the Dapingian-Darriwilian boundary, is re-discussed based on the results herein. The uppermost part of the Sajir Member yielded the ichnofossil, Phycodes fusiforme. Acritarch assemblages from the Sajir Member of the Saq Formation are poorly diversified and dominated by sphaeromorphs. More diverse assemblages of acritarchs, associated with enigmatic forms, occur in the Hanadir Member of the Qasim Formation. The contact between the two formations and the transition between the palynomorph assemblages are sharp, suggesting a stratigraphic hiatus. A quantitative analysis allows us to discuss the paleoenvironmental changes and possibly climatic changes associated with an hypothesis of ice house conditions during this period. Among the diagnostic acritarch taxa observed are Frankea breviuscula, F. longiuscula, Baltisphaeridium ternatum, Dasydorus cirritus, Dicrodiacrodium ancoriforme, Poikilofusa ciliaris, Pterospermopsis colbathii and Uncinisphaera fusticula. These are associated with other typical forms known to range across the Lower-Middle Ordovician boundary, such as Aremoricanium rigaudae, Aureotesta clathrata, Barakella fortunata, B. rara, Baltisphaeridium klabavense, Glaucotesta latiramosa and Striatotheca spp. Galeate and peteinoid acritarchs are also well represented, as well as tiny forms of ultraplanctonic size. Three new species of acritarchs are proposed: Frankea longiuscula var. darriwilense var. nov, Micrhystridium regulum sp. nov, and Tyrannus proteus sp. nov. Repeated occurrences throughout the section of cryptospores, problematic microfossils such as organic filaments, cuticle-like tissues, striated and pigmented leiospheres frequently in clusters, are interpreted to reflect recurrent terrestrial and freshwater inputs in the depositional environment. Single-specimen, highresolution analyses using Confocal Laser Scanning Microscopy on the enigmatic form Tyrannus proteus sp. nov. show fluorescence emission spectra and microstructural properties significantly different from those of typical marine acritarchs from the same levels.
\end{abstract}

(C) 2017 Elsevier Masson SAS. All rights reserved.

Keywords: Acritarchs; Microphytoplankton; Ultraplankton; Darriwilian; Palynology; Ordovician glaciation

\footnotetext{
* Corresponding author.

E-mail addresses: alain.le.herisse@ univ-brest.fr (A. Le Hérissé), marco.vecoli@aramco.com (M. Vecoli).
}

\section{Introduction}

Several key papers published over the past years discussed the possibility of an "Early Paleozoic Ice Age" (Pohl et al., 2016) since the Darriwilian. This hypothesis could contradict the concept of long-term global greenhouse climate stability 
during most of the Ordovician, before the cooling interval of the Late Ordovician. Arguments of a glacial onset that may have occurred as early as the Darriwilian at the Gondwanan paleoSouth pole, predating the Hirnantian glacial maximum (Ghienne et al., 2007), are sedimentological, geochemical, micropaleontological or related to the paleogeographical configuration (Dabard et al., 2015; Thompson, 2011; Trotter et al., 2008; Turner et al., 2012; Pohl et al., 2014; Pohl et al., 2016; Rasmussen et al., 2016; Vandenbroucke et al., 2010a, b, etc.). Since the present contribution deals with the palynology of Gondwanan rocks of ?Dapingian to Darriwillian age, it is interesting to consider whether palynomorph assemblages from borehole QSIM-801 have any bearing on the hypothesis of precocious cooling in the Middle Ordovician.

As previously discussed by Le Hérissé et al. (2007), the sediments of borehole QSIM-801 yielded rich assemblages of marine palynomorphs (acritarchs, prasinophycean phycomata, chitinozoans), but also some cryptospores and microscopic plant remains. Many palynomorphs are also enigmatic, not previously described, and we discuss unreported minute microfossils of picoplanktonic and ultraplanktonic size, which are key components of the assemblages. The chitinozoan data provide a robust biostratigraphic framework, and we also discuss the biostratigraphic potential of the acritarchs and prasinophycean phycomata assemblages, with the view to improve the somewhat unsatisfactory biostratigraphic control for the Saq/Hanadir transition in this area.

After the first occurrence of Middle Ordovician cryptospores was revealed in a stratigraphically equivalent interval in Saudi Arabia (Strother et al., 1996), more recent findings (Strother et al., 2015; Steemans et al., this volume) confirm their importance and the establishment of a non negligible vegetation cover during this period. In borehole QSIM-801, the relative abundance of cryptospores ranges between 6 to more than $8 \%$ of total palynomorphs (see Section 5.2).

The shales of the Hanadir Member of the Qasim Formation contain also abundant Amorphous Organic Matter (AOM) (up to $30 \%$ of total kerogen content), with subsidiary opaque material. This possibly reflects high burial rates of organic carbon during the Darriwilian, which, in association with a primordial vegetation cover, could have affected both sedimentary processes and climate. The question is to know if their combined effect could have been sufficient to significantly draw down atmospheric $\mathrm{CO}_{2}$ and to cause transient cooling of the global climate.

To achieve a high temporal resolution and to discuss the specific characteristics of the assemblages (e.g., the abundance of minute palynomorphs, or the over-representation of some taxa), we provide a detailed quantification of the variations in palynomorph assemblages. This allows us to reconstruct both terrestrial and aquatic changes along the succession, and to relate these changes to sea-level fluctuations, complementing the sedimentological data. A further remit of the present study is to evaluate the hydrocarbon exploration potential of the Saq/Hanadir transition, both in terms of reservoir-seal as well as source rock association, in analogy with the Upper Ordovician Sarah Formation and the overlying lower Silurian hot shales of the Qusaiba Member of the Qalibah Formation.

\section{Geological setting and biostratigraphy}

A thick and well-preserved Ordovician succession is exposed and penetrated on the eastern border of the Arabian Precambrian Shield (Fig. 1, Vaslet et al., 1987). In the regional lithostratigraphy, the Tabuk Formation of Steinecke et al. (1958), amended by Powers et al. (1966), is substituted now, in ascending order, by the upper part of the Saq Formation (also named Anz Formation by Khalifa, 1993, 2015), the Hanadir, Kahfah, Ra'an and Quwarah members of the Qasim Formation, and glacial and periglacial deposits referred to as the "Sarah-Zarqa" Formation (Vaslet, 1990; Melvin, 2015). The Saq and Qasim formations extend, with their stratigraphic equivalents, into Jordan to the North and to Oman in the South (Stump, 1995; Al-Hajri, 1995).

Penetrating a $1200 \mathrm{ft}$ thick Ordovician sequence, Borehole QSIM-801 (Fig. 1), was drilled to test the Saq aquifer and, secondarily, to evaluate the source rock potential of these series. The studied section is relatively short and concerns only a midOrdovician cored interval of $93 \mathrm{ft}$, penetrating from top to the bottom, the Hanadir Member of the Qasim Formation and the Sajir Member in the uppermost part of the Saq Formation.

In this paper, the global chronostratigraphy for the Middle Ordovician Series proposed by Webby et al. (2004) is used, subdividing the Series into the Dapingian and Darriwilian Stages, even though this scheme introduces many problems for intercontinental correlations. The difficulty arises because the faunas used for the definition of stratotypes in deep-water facies of Canada and China are hardly recognized in inner-shelf facies of the south polar Gondwana and peri-Gondawanan areas. For this reason, some regional schemes have been recently introduced, such as the Bohemo-Iberian (= "Mediterranean") chronostratigraphic scale in the South Gondwana paleobiogeographical region (Gutiérrez-Marco et al., 2016).

On the Arabian shield, the mid-Ordovician corresponds to a period of increased subsidence that led to a major transgression, marked by a maximum flooding surface (MFS), placed in the Darriwilian. This stratigraphic interval corresponds to the upper part of the Arenigian, Oretanian to part of the Dobrotivian in the Bohemia-Iberian chronostratigraphic scale of Gutiérrez-Marco et al. (2016). This Darriwilian MFS, named O30, is comparable in importance to the S10 in the early Silurian (Haq and AlQhatani, 2005). Sharland et al. (2001) located MFS O30 within the Hanadir Shale sequence and correlated it regionally across the Arabian Plate (Senalp and Al-Duaiji, 2001). Sedimentologically, the boundary between the Saq and Qasim formations in QSIM-801, has been placed at $751 \mathrm{ft}$, corresponding to the transition between a tidal sand flat environment (Sajir Member of Saq Formation) and a distal delta front (Hanadir member of Qasim Formation). In the QSIM-801 core, the Sajir sandstoneHanadir shale contact is sharp and markedly erosional. This is quite distinct from the contact throughout most of cored sections elsewhere in Saudi Arabia, where the transition is considered continuous and conformable. In the North of Saudi Arabia, a MFS is observed at the base of the Hanadir Member, but this is not seen in the QSIM-801 well.

Age assignments are of prime importance in the calibration of sedimentary and palynological events (e.g., Murthy et al., 2015). 

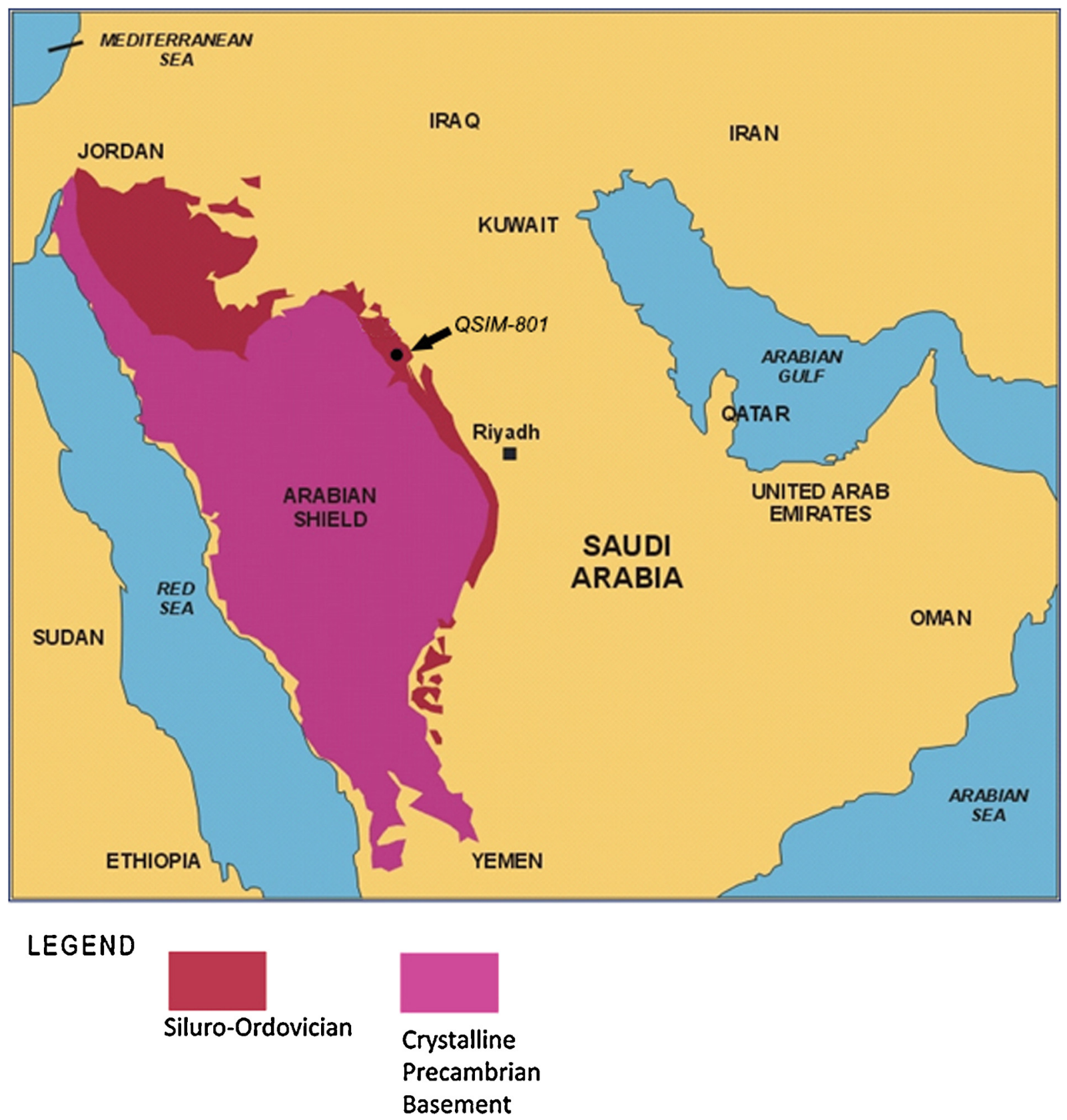

Fig. 1. Geological map showing the location of the QSM-801 water well, central Saudi Arabia.

Previously, the biostratigraphic age of the Sajir Member has been considered to span the Dapingian-Darriwilian boundary, but based on the palynological results of this study, and in particular the distribution of chitinozoans, we think this age should be reconsidered. Ichnofossils of regional interest in Saudi Arabia, such as the Cruziana or Phycodes fusiforme, occur in the upper part (Sajir Member) of the Saq Formation, particularly in sandstones of core 8 in QSIM-801. The Hanadir Member contains graptolites such as Didymograptus cf. bifidus and Didymograptus protobifidus (Helal, 1964; Powers, 1968), ostracods, conodonts and trilobites (Vaslet et al., 1987). Moreover, some trace fossils are also present at the Saq/Hanadir boundary (ElKhayal and Romano, 1988; Seilacher, 2000). The details of sedimentary facies and faunas have been described in a previous paper (Le Hérissé et al., 2007), and supplementary information on other stratigraphically equivalent localities can be found in Ghavidel-Syooki et al. (2014) and Gutiérrez-Marco et al. (2016). The age of the Hanadir Member, originally regarded as Early Ordovician (Helal, 1964), was re-assigned on palynological evidence to the Darriwilian, i.e., late Arenig to Llanvirn of the British terminology (Al-Hajri, 1995). Chitinozoans of the bulla biozone of early Darriwilian age, which in northern Gondwana is generally associated to a deepening pulse of the depositional environment, have been described from the uppermost part of the Saq Formation in some parts of Saudi Arabia (Paris, personal communication, Paris et al., 2007). This is the first contradiction with a Dapingian age attributed to the upper Saq Formation in the regional charts (Sharland et al., 2001). 
The stratigraphy of the Dapingian to early Darriwilian interval is complex all over the world (Gutiérrez-Marco et al., 2013, 2016), and particularly on the Arabian margin of Gondwana, where it is characterized by condensed sequences and diastems in Oman (Molyneux et al., 2006), Iran (Ghavidel-Syooki et al., 2014), and Saudi Arabia (Le Hérissé et al., 2007; present study).

The chronostratigraphical control for QSIM-801 is established on the presence of two successive chitinozoan biozones: the Siphonochitina formosa zone and the L. pissotensis biozone. The first appearance and good representativity of $S$. formosa, in the uppermost Saq Formation, at $759.6 \mathrm{ft}$, top of core 8 and higher, defines our older assemblage. In north Gondwana, S. formosa is considered the index species of the eponym zone, and is dated as late-early Darriwilian. It is considered equivalent to the $D$. artus graptolite Zone, and is associated with a major flooding episode (Paris et al., 2007). This zone and its associated flooding event are also known in Oman (Molyneux et al., 2002) and south eastern Iran, where it occurs above an important hiatus encompassing the Dapingian-earliest Darriwilian interval (Ghavidel-Syooki et al., 2014).

The presence of the $S$. formosa biozone constrains the age of the Sajir Member in QSIM-801, to the late-early Darriwilian. A similar situation in the upper part of the Saq Formation, was previously reported from other localities in Saudi Arabia, as mentioned by Guttiérrez-Marco et al. (2013, p. 4), where an unusual assemblage of chitinozoans from the ?D. ornensis to $B$. henryi biozones and conglomeratic beds with lingulids are overlain by bedded sandstones yielding the first middle Darriwilian graptolites (El-Khayal and Romano, 1988; Al-Hajri, 1995). The upper part of the studied section in QSIM-801, from cores 3 to 1 (699.9-675.1 ft) is more congruent with an age of late Darriwilian, referring to the L. pissotensis chitinozoan biozone, which coincides also pro parte with a transgressive event, corresponding to MFS O30 by Sharland et al. (2001).

Considering that the Ordovician chitinozoan biozones span a time interval of less than $3 \mathrm{Myr}$ (Paris et al., 2007), and that the pissotensis biozone is probably not complete in the QSIM-801 section, we realize that the late Dapingian (?)-early Darriwilian to mid to late Darriwilian sequence in the QSIM801 section is very condensed, corresponding to less than $100 \mathrm{ft}$.

\section{Material and methods}

A total of 42 samples were collected across the boundary between the Sajir Member of the Saq Formation and the Hanadir Member of the Qasim Formation in borehole QSIM-801. All the samples were processed using standard palynological techniques. A first batch of samples was treated in the palynological laboratory of Saudi Aramco, and first results on this material were published by Le Hérissé et al. (2007). Another set of samples was processed both in the palynological laboratories of the University of West Brittany (Brest, France) and the University of Liège (Belgium). In Brest, modified palynological techniques comprising very soft acid digestion, without centrifugation, oxidation and further manipulation for separation of heavy minerals, were used to obtain more complete specimens (e.g. with possible connections between specimens) of the most enigmatical forms. Unfiltered palynological residues were also studied, in order to analyze the smaller palynomorphs (ultraplankton).

In addition to conventional transmitted light microscopy, Scanning Electronic Microscopy (SEM) and Confocal Laser Scanning Microscopy (CLSM) were applied to selected species, for details of morphological features. Confocal Laser Scanning Microscopy (CLSM) is an important technique largely used in the biomedical sciences to image in situ cellular material to micro- and nano-scale resolution (Pawley, 2006). In geological sciences the CLSM has most often been used for imaging delicate morphological features of palynomorphs (e.g. FeistBurkhardt and Pross, 1999). The CLSM of the University of Brest used in the present study is a Zeiss LSM 780 with a $\times 50$ Epiplan Apochromat objective AN 0.95, using Ar 405 nm excitation. CLSM microscopy was mainly used to analyze the variations in autofluorescence spectra between the enigmatical form Tyrannus proteus sp. nov., and other species assigned to the acritarchs.

Each examined specimen was characterized by two fluorescent spectral profiles, with a specific colored bullet illustrating variations of excitation of the autofluorescence on several parts of the specimens.

Quantitative changes in palynomorph assemblage composition and diversity were also measured within the cored section, with a count of at least 300 palynomorph specimens per sample. Relative abundance of AOMs compared to palynomorphs has also been established separately. AOMs comprises all particulate organic components that appear structureless at the scale of light microscopy.

Pyrite framboids and sulfur-rich nannospheres occur abundantly in the organic residues, particularly in samples from the Hanadir Member. This sedimentary pyrite can be formed by the reaction of $\mathrm{H}_{2} \mathrm{~S}$ produced by bacterial sulfate reduction with detrital iron minerals, and decomposition of organic matter, and can indicate a chemically reducing depositional environment under anoxic conditions (Raiswell and Berner, 1986). Abundant and well-preserved AOM is frequently associated with pyrite. This confirms that the Hanadir Member was mainly deposited under anoxic conditions. However, the fluctuations in relative abundance of AOM vs. marine and/or terrestrial palynomorphs in QSIM-801, also suggest periodic exposure to dysoxic conditions. The organic matter of the Hanadir Member is highly mature type II kerogen with range of total organic carbon (TOC) between 0.5 to $2.98 \%$ (Ghazwani, 2012), that indicates the source rock of the Hanadir is in Gas generation windows.

All illustrated specimens (Plates 1 to 7), from palynological slides prefixed SA 8219, SA 44845, 44850, 44851, 44852.2, 44853.2, 44857.2, 44858.2, 44861.2, 44862.2, 44881, 44881.2, 44883.1, 44883.2, 44888, 44888.2, 44890, 44891.2, 44894.2, and LPB 13071 to 13085, are deposited in the collections of Saudi Arabian company in Dhahran, and the Laboratoire de Paléontologie de Brest (LPB), France. 

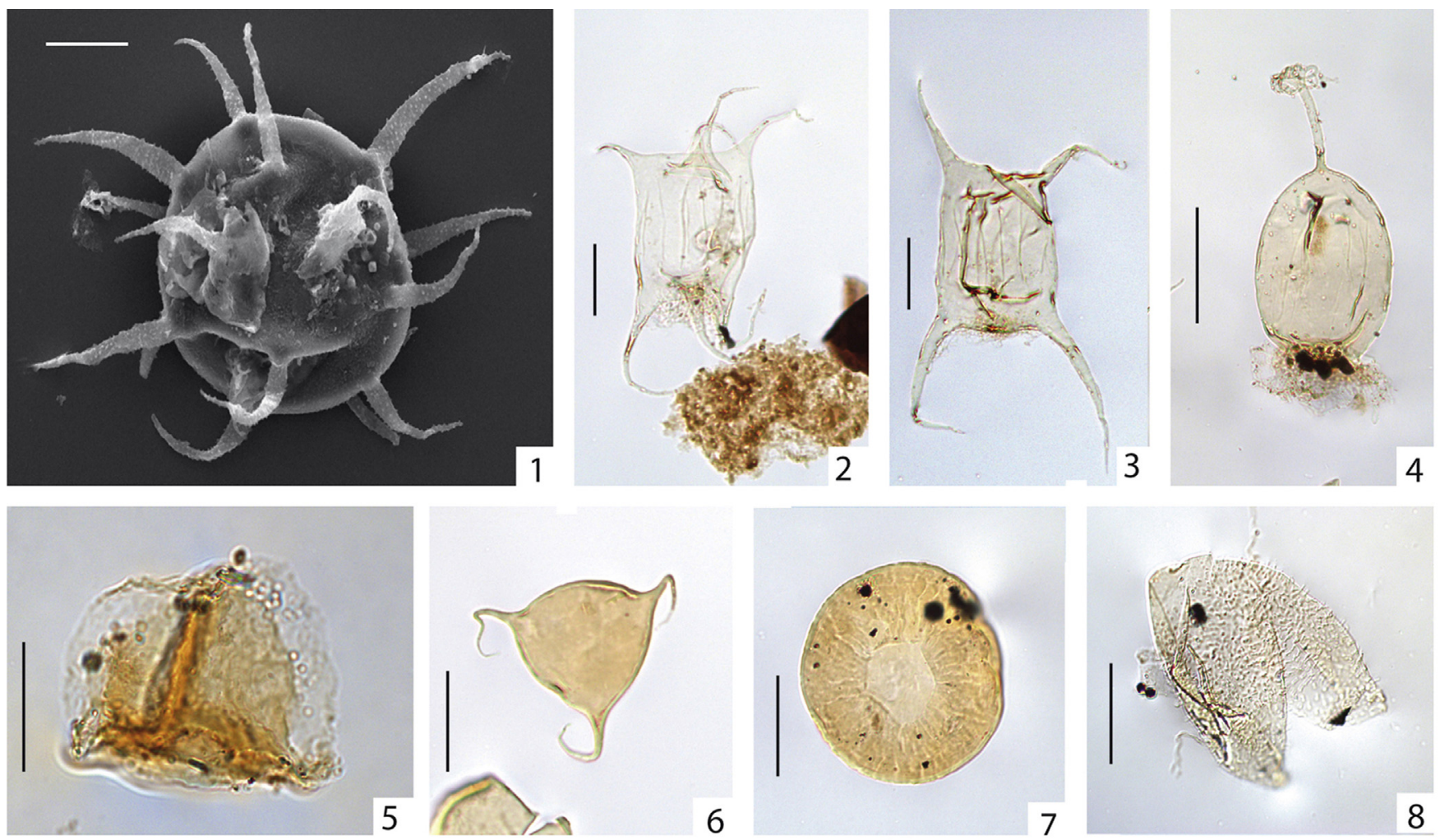

6

8
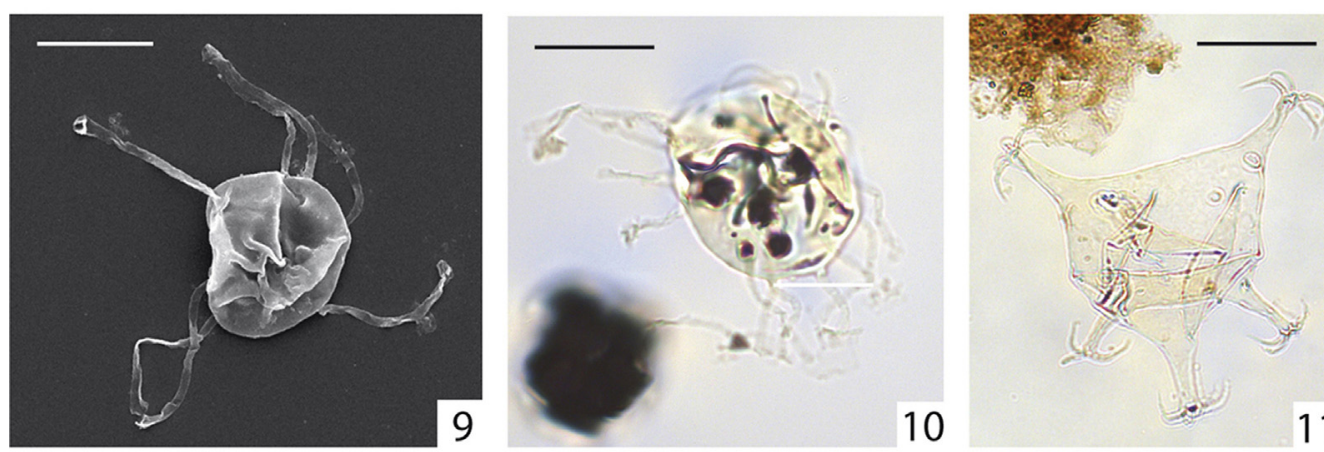

10
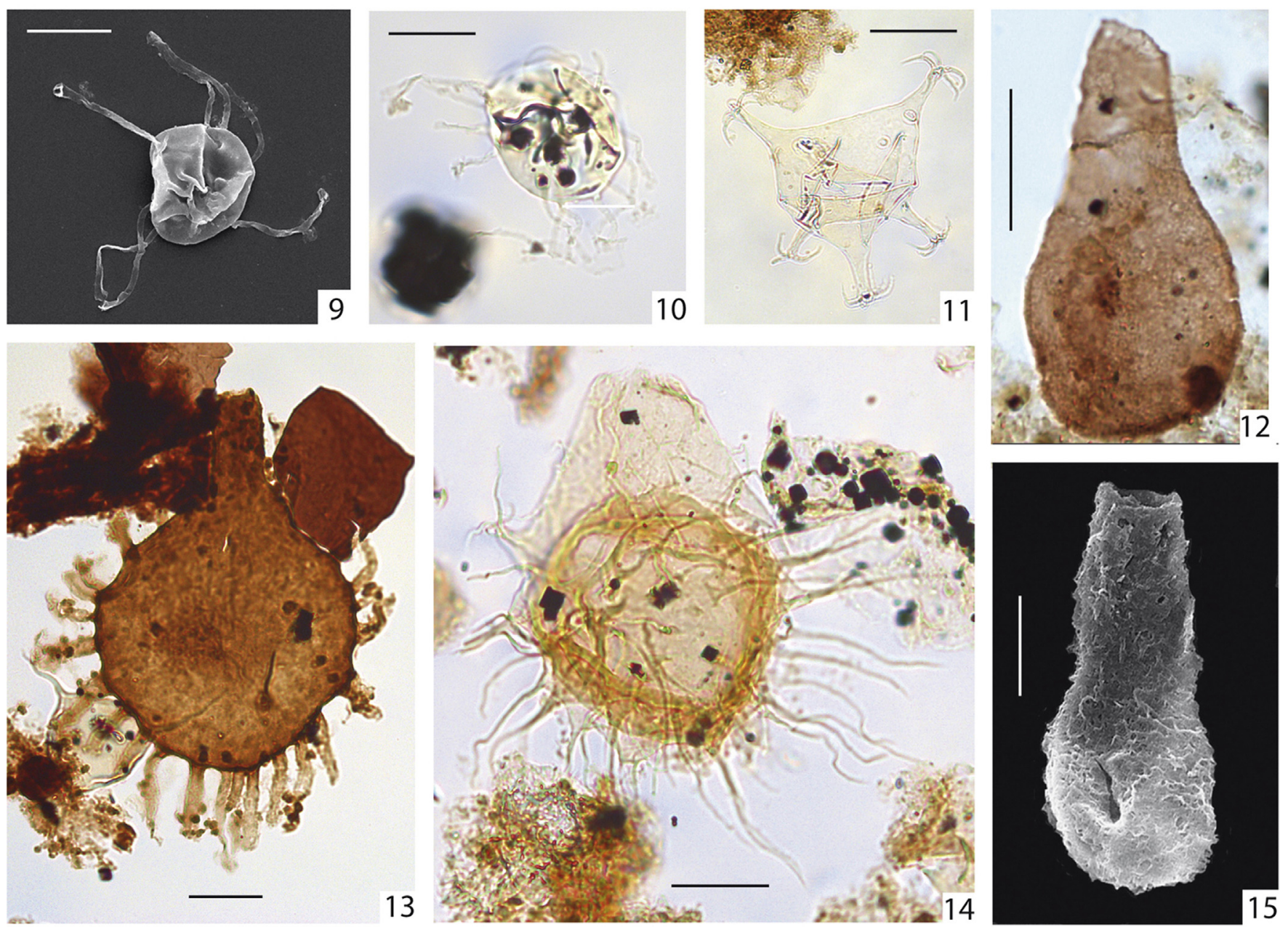


\section{Systematic paleontology}

Two new species and one new variety of acritarch are described and one species is revised. All palynomorph taxa mentioned in the text are listed with authorship in alphabetical order in Appendix 1. Problematic organic-walled microfossils are also described herein, grouped under the informal category "unidentified grey elements".

\subsection{Algae Incertae Sedis}

Group ACRITARCHA Evitt, 1963

Genus Focusphaera Quadros, 1986

Type species. Focusphaera elongata Padilha de Quadros, 1986.

Focusphaera elongata Padilha de Quadros, 1986

Plate 1, Figs. 12, 15

1986 Focusphaera elongata Padilha de Quadros, p. 184-186, Plate 2, figs. 5-10.

2007 ?Tinacula sp. A, Le Hérissé, Al-Ruwaili, Miller, Vecoli, p. 10, 12, Plate 2, figs. 10-12.

Description. Vesicle piriform, elongate in outline, base subspherical and unobstructed neck-like extension. The surface of the vesicle varies from microgranulate, reticulate, baculate or with pilosity. The open distal end of the neck-like structure is simple and slightly constricted.

Remarks. The specimens described and illustrated in Le Hérissé et al. (2007) were misidentified as ?Tinacula sp.; on the basis of comparison with type material of Focusphaera elongata (Quadros, personal communication) these specimens are reassigned to the latter species. Consequently, the present Middle Ordovician assemblages from Saudi Arabia show interesting elements of comparison with the Middle Ordovician of the Benjamin Constant Formation in the Solimões Basin, Brazil (Quadros, 1986a, 1986b, 1988). The Darriwilian Hanadir Member of the Qasim Formation in Saudi Arabia, contains also Barakella fortunata and Striatotheca rarirrugulata, both likewise found in the Solimões Basin.
Dimensions. Total length, 36-75 $\mu \mathrm{m}$; vesicle diameter, 29-45 $\mu \mathrm{m}$; diameter of distal opening, 12-18 $\mu \mathrm{m}$ (ca. $55 \mathrm{spec}-$ imens measured).

Occurrence. Restricted to the Hanadir Member of the Qasim Formation, from top of Core 7 to core 1, Zone 3, middle to late Darriwilian.

Genus Frankea (Burmann, 1970) Servais, 1993 emend.

1970 Frankea Burmann, p. 292

1993 Frankea Burmann emend., Servais, p. 80

1995 Fatkia Vavrdová, p. 368

Type species. Frankea hamata Burmann, 1970 by original designation.

Original diagnosis. Der Zentralkörper ist triangular, mit dreistrhliger Anordnung von Fortsätzen, die terminal an eimen gemeinsamen Ansatzpunkt in unverzweige Anhänge aufgabeln. Die Anzahl der terminalen Fortsatznhänge (Zwei und mehr) und das Längenverhältnis von Fortsatz zu Zentralkörper sind variabel (Burmann, 1970).

Translation of the original diagnosis. The central body is triangular, with a triradial arrangement of the processes, which split distally from simple point into unbranched pinnae. The number of the terminal pinnae (two or more) and the ratio of process length to central body diameter are variable.

Emended diagnosis. Vesicle subcircular to triangular in outline, bearing generally three processes, but sometimes only two or up to four. The processes are cylindrical, hollow, of variable size, but relatively constant in length within each specimen. The processes are in free communication with the vesicle interior, but the communication can be restricted in some species by means of a plug at the base of the processes. The processes split distally from a single point into two or more pinnae. Sometimes one process can be simple. The surface of the vesicle and of the processes is smooth to granulate or striatogranulate. Opening by means of an epityche.

Remarks. Servais (1993, p. 81) underlined the importance of the number of terminal pinnae and the ratio of process length to central body diameter for circumscription and differentiation of the species of Frankea. Other observations (Vecoli et al., 1999a) and the material studied here, do not support this assertion.

Plate 1. Acritarchs from QSIM-801 Well, Saudi Arabia. Key to abbreviations: SA, Saudi Aramco collection; LPB, Laboratory of Paleontology of Brest collection; EF, England Finder coordinates. Scale bar $20 \mu \mathrm{m}$ for all figured specimens. Fig. 1. Baltisphaeridium klabavense (Vavrdová) Kjellström, 1971. $728.5 \mathrm{ft}$, slide LPB 13071 (EF O33/4); SEM view; diameter of central body, $67 \mu \mathrm{m}$; process length, $45 \mu \mathrm{m}$. Fig. 2. Barakella rara (Lu Li-chang) emend. Tongiorgi et al., 1995. $719.9 \mathrm{ft}$, slide SA 44881 (EF E54/1); dimensions of central body, $45 \times 35 \mu \mathrm{m}$; process length, $39 \mu \mathrm{m}$. Fig. 3. Barakella fortunata Cramer and Diez, 1977. $719.9 \mathrm{ft}$, slide SA 44881 (EF P62/3); dimensions of central body, $45 \times 33 \mu \mathrm{m}$; process length, $39 \mu \mathrm{m}$. Fig. 4. Dicrodiacrodium ancoriforme Burmann, 1968 emend Servais et al., 1996. $719.9 \mathrm{ft}$, slide SA 44881 (EF D49); dimensions of central body, $33 \times 25 \mu \mathrm{m}$; process length, $17 \mu \mathrm{m}$. Fig. 5. Cymatiosphaera sp. $702.7 \mathrm{ft}$, slide SA 44858.2 (EF G58/1); diameter of central body, $33 \mu \mathrm{m}$; height of membranous crests, $6 \mu \mathrm{m}$. Fig. 6. Veryhachium trispinosum group. $719.9 \mathrm{ft}$, slide SA 44881 (EF F48/4); diameter of central body, $31 \mu \mathrm{m}$; process length, $11 \mu \mathrm{m}$. Fig. 7. Virgatasporites rudii Combaz, 1967. $699.9 \mathrm{ft}$, slide SA 44857.2 (EF P49/4); vesicle diameter, $45 \mu \mathrm{m}$. Fig. 8. Dasydorus cirritus Playford and Martin, 1984. 682.2 ft, slide SA 44850 (EF S53). Vesicle length, $50 \mu \mathrm{m}$; vesicle width, $30 \mu \mathrm{m}$. Figs. 9 , 10. Glaucotesta latiramosa Vavrdová, 1982. Fig. 9: 712.7 ft, slide LPB 13075 (EF L26/4), SEM view; vesicle diameter, $22 \mu \mathrm{m}$; process length, $15 \mu \mathrm{m}$. Fig. $10: 712.7 \mathrm{ft}$, slide LPB 13074 (EF F46/2); vesicle diameter, $22 \mu \mathrm{m}$; process length, $15 \mu \mathrm{m}$. Fig. 11. Frankea breviuscula Burmann, 1970. $717.9 \mathrm{ft}$, slide SA 44862.2 (EF F52), variant with 5 processes; vesicle diameter, $28 \mu \mathrm{m}$, process length, $14 \mu \mathrm{m}$. Figs. 12, 15. Focusphaera elongata Quadros, 1986. Fig. 12: 675.1 ft, slide SA 44853.2 (EF K50/3), specimen with a microgranulate surface; diameter of rounded base, $28 \mu \mathrm{m}$; diameter of apical part (including the opening), $12 \mu \mathrm{m}$; total length, $56 \mu \mathrm{m}$. Fig. 15: $712.7 \mathrm{ft}$, slide LPB 13075 (EF L25), SEM view; rounded base, $45 \mu \mathrm{m}$ in diameter; diameter of apical part, $22 \mu \mathrm{m}$; total length, $89 \mu \mathrm{m}$. Fig. 13. Aremoricanium aff. A. squarrosum Loeblich and Mac Adam, 1971. $717.9 \mathrm{ft}$, slide SA 44862.2 (EF P48/3); diameter of central body, $75 \mu \mathrm{m}$; length of neck, $22 \mu \mathrm{m}$; length of processes, $15-17 \mu \mathrm{m}$. Fig. 14. Aremoricanium rigaudae Deunff, 1955. $717.9 \mathrm{ft}$, slide SA 44862.2 (EF H39); dimensions of central body, $75 \times 55 \mu \mathrm{m}$; length of neck, $30 \mu \mathrm{m}$, length of processes, $33 \mu \mathrm{m}$. 

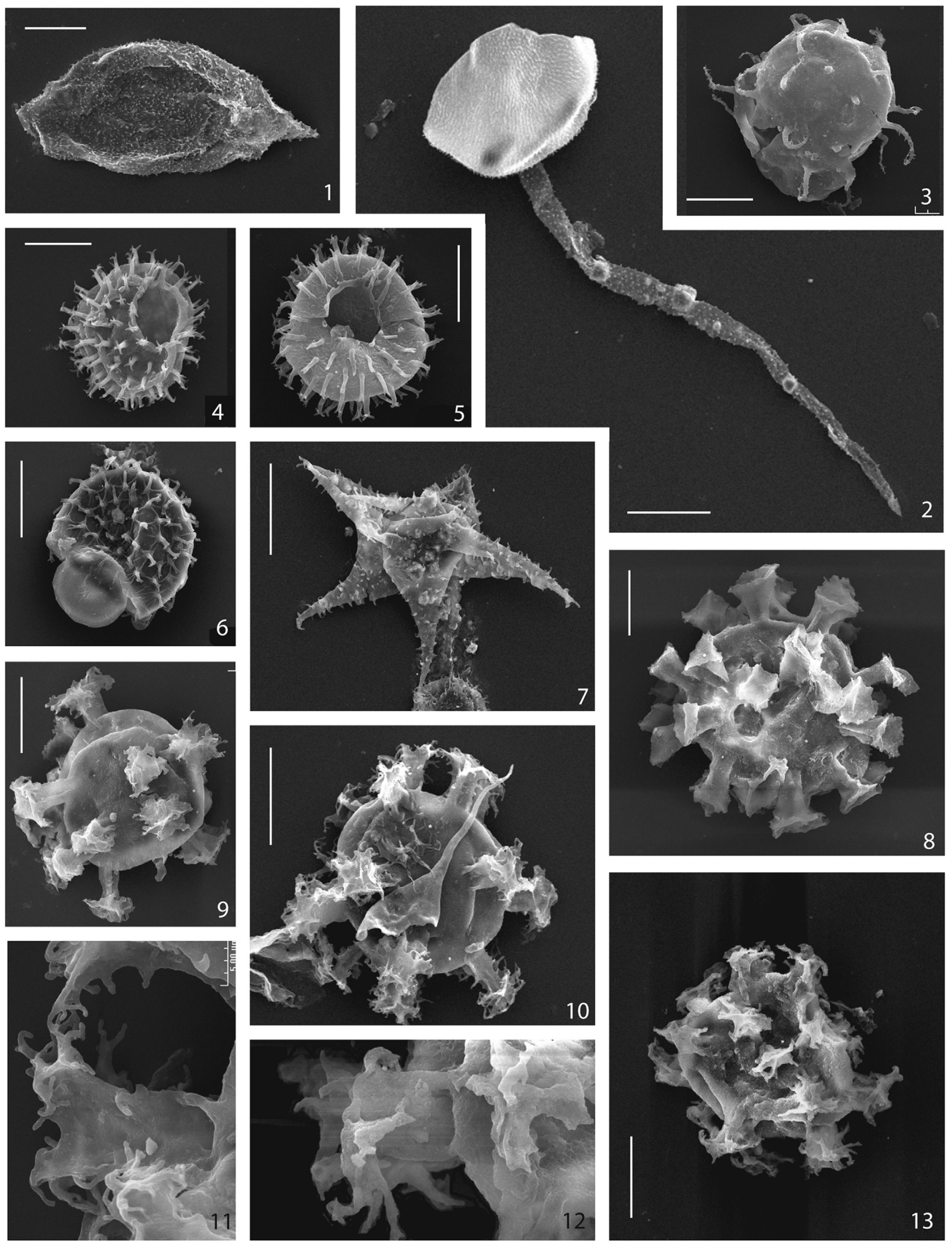
The vesicle wall thickness is variable. In the majority of the specimens observed, the communication between the processes and vesicle interior is evident. However, some specimens show a strong contrast between a thicker-walled vesicle and thickening extension at the base of the processes and a thinner wall for the rest of the trunk of the processes up to the top. This suggests, for some Frankea species, a sharp separation between process and vesicle cavities.

The genus was proposed by Burmann (1970), based on observations in thin sections, and of particular interest is one of the illustrations of Frankea longiuscula (Burmann, 1970, Plate 2 , fig. 12), that clearly shows a thicker-walled vesicle. Neither the successive emendations of the genus by Colbath (1986) and Servais (1993), nor the discussions and remarks on the genus by Fatka et al. (1997) and Vecoli et al. (1999a, b) discuss the variability in wall thickness, which is especially apparent in some specimens of Frankea longiuscula. We consider this feature in context with the description of Frankea longiuscula var. darriwilense var. nov.

Frankea longiuscula var. darriwilense var. nov.

Plate 3, Figs. 1-4, 7, 9, 11, 12; Plate 6, Fig. 6; Text-Fig. 2.

1970 Frankea longiuscula Burmann, Plate 2, fig. 12, Plate 3, figs. 1, 2.

1977 Multiplicisphaeridium longiusculum (Burmann) Eisenack, Cramer and Diez in Cramer and Diez, Plate 6, fig. 16.

?1999 Frankea longiuscula Burmann, 1970 - Vecoli, Tongiorgi, Playford, Plate 2, fig. 2.

?2000 Veryhachium subglobosum Jardiné et al., 1974 Molyneux and Al-Hajri, plate 2, b.

2007 Frankea longiuscula Burmann, 1970 - Le Hérissé, AlRuwailii, Miller, Vecoli, Plate 1, figs. 12, 14, 15.

Derivation of name. From Darriwilian, stage of the Middle Ordovician.

Typification. Holotype, borehole QSIM-801, level $715.6 \mathrm{ft}$, core 4, slide SA 44861.2 (EFS48/1), Plate 3, Fig. 7.

Type locality and horizon. borehole QSIM-801, Hanadir Shale Member, Quasim Formation, middle to late Darriwilian.

Diagnosis. A variety of Frankea longiuscula Burmann, 1970, which differs in having a darker and thicker-walled vesicle, and an important variability in the termini of processes, in the form and number of pinnae.
Description. Vesicle subtriangular to subcircular in outline, with convex sides, bearing three long and cylindrical processes (rarely one additional process present), one located at each angle of the vesicle. The processes are distally simple or splitting into two and up to 12 pinnae. The vesicle and proximal part of the processes are distinctly darker and thicker than the rest of the processes. Vesicle and process surface smooth to microgranulate. Excystment by means of an epityche ("horse-shoe" opening) between two processes.

Dimensions. Vesicle diameter, 29-61 $\mu \mathrm{m}$; process length, 45-92 $\mu \mathrm{m}$; process width $2.5-3 \mu \mathrm{m}$; length of pinnae 5.5-11 $\mu \mathrm{m}$; vesicle wall thickness, $1.2 \mu \mathrm{m}$ (more than 500 specimens measured).

Remarks. This variety is well represented in zones 2 and 3 (late-early to late Darriwilian), attaining $10 \%$ up to $15 \%$ of the total assemblage in several levels. The high percentages are intermittent in the succession, suggesting recurrences of "blooms".

This taxon is characterized by well-developed processes, but also by important morphological variability leading to teratological specimens, which are observed throughout the section (e.g., Plate 3, Fig. 9; Fig. 2).

In addition to the illustrations of Burmann (1970) that suggest more important variability in Frankea longiuscula than indicated in the original description, Cramer and Diez (1977, p. 350) noted, in their Moroccan material, that some Frankea longiuscula were consistently darker and thicker-walled, so that they even considered a separate species for these specimens. Because we have in our material some true Frankea longiuscula (thin-walled, no darker vesicle wall), we suggest that the darker and thickerwalled forms constitute a variety rather than a new species. This separation into a subspecific category (e.g., Servais and Molyneux, 1997), is of practical utility for retaining stratigraphic and paleoenvironmental information.

In the literature, wall thickness has been considered both as a specific and as a subspecific (varietal) character, together with the presence/absence of process basal plugs. An example of the former case is the Silurian species Veryhachium checkleyensis Dorning, 1981. An example of intra-specific variability based on thickness wall is found in the discussion of the Cambrian species Lusatia dendroidea by Albani et al. (2007): "The free communication of processes with the vesicle interior is evident in translucent and thin-walled specimens. Specimens with a dark,

Plate 2. Acritarchs from QSIM-801 Well, Saudi Arabia. Key to abbreviations: LPB, Laboratory of Paleontology of Brest collection; EF, England Finder coordinates. Scale bar $20 \mu \mathrm{m}$ for all figured specimens. Fig. 1. Poikilofusa ciliaris Vecoli, 1999. $728.5 \mathrm{ft}$, slide LPB 13071 (EF M33/4); dimensions of central body, $38 \times 80 \mu \mathrm{m}$; length of polar extensions, $22 \mu \mathrm{m}$. Fig. 2. Baltisphaeridium ternatum (Burmann) emend. Vecoli, 1999. $728.5 \mathrm{ft}$, slide LPB 13071 (EF M30/2); diameter of central body, $44 \mu \mathrm{m}$; length of processes, $123 \mu \mathrm{m}$. Fig. 3. Unicinispahera fusticula Vecoli, 1999. $728.5 \mathrm{ft}$, slide LPB 13071 (EF L35/2); diameter of central body, $45 \mu \mathrm{m}$; length of processes, 17-20 $\mu \mathrm{m}$. Figs. 4, 5. Stelliferidium striatulum (Vavdová) Deunff, Górka \& Rauscher, 1974. Fig. 4: 728.5 ft, slide LPB 13071 (EF O34/1); diameter of central body, $42 \mu \mathrm{m}$; length of processes, $5 \mu \mathrm{m}$. Fig. 5: $728.5 \mathrm{ft}$, slide LPB 13072 (EF L30/4); diameter of central body, $39 \mu \mathrm{m}$; length of processes,

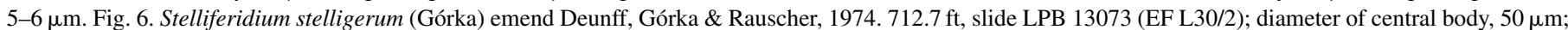
length of processes, $5 \mu \mathrm{m}$; diameter of pylome, $28 \mu \mathrm{m}$. Fig. 7. Stellechinatum celestum (Martin) Turner, 1984. $712.7 \mathrm{ft}$, slide LPB 13073 (EF N31); diameter of central body, $33 \mu \mathrm{m}$; length of processes, $28 \mu \mathrm{m}$. Fig. 8, 9. Peteinosphaeridium velatum Kjellström, 1971 emend. Playford, Ribecai \& Tongiorgi, 1995. Fig. 8: $728.5 \mathrm{ft}$, slide LPB 13072 (EF O34); diameter of central body, $70 \mu \mathrm{m}$; length of processes, $20 \mu \mathrm{m}$. Fig. 9: $728.5 \mathrm{ft}$, slide LPB 13072 (EF L32/3); diameter of central body, $43 \mu \mathrm{m}$; length of processes, $13 \mu \mathrm{m}$. Figs. 10, 11. Peteinosphaeridium aff. P. bergrstroemii, Staplin, Jansonius \& Pocock, 1965 emend. Playford, Ribecai \& Tongiorgi, 1995. Fig. 10: $728.5 \mathrm{ft}$, slide LPB 13072 (EF O32); diameter of central body, $60 \mu \mathrm{m}$; length of processes, 12-15 $\mu \mathrm{m}$. Fig. 11: Same specimen as in Fig. 10, detail of process ornamentation. Figs. 12, 13. Peteinosphaeridium sp. A. Fig. 13: $712.7 \mathrm{ft}$, slide LPB 13073 (EF O32/2), complete specimen; diameter of central body, $45-47 \mu$ m; length of processes, $15 \mu \mathrm{m}$. Fig. 12: Same specimen as previous, detail of process ornamentation. 

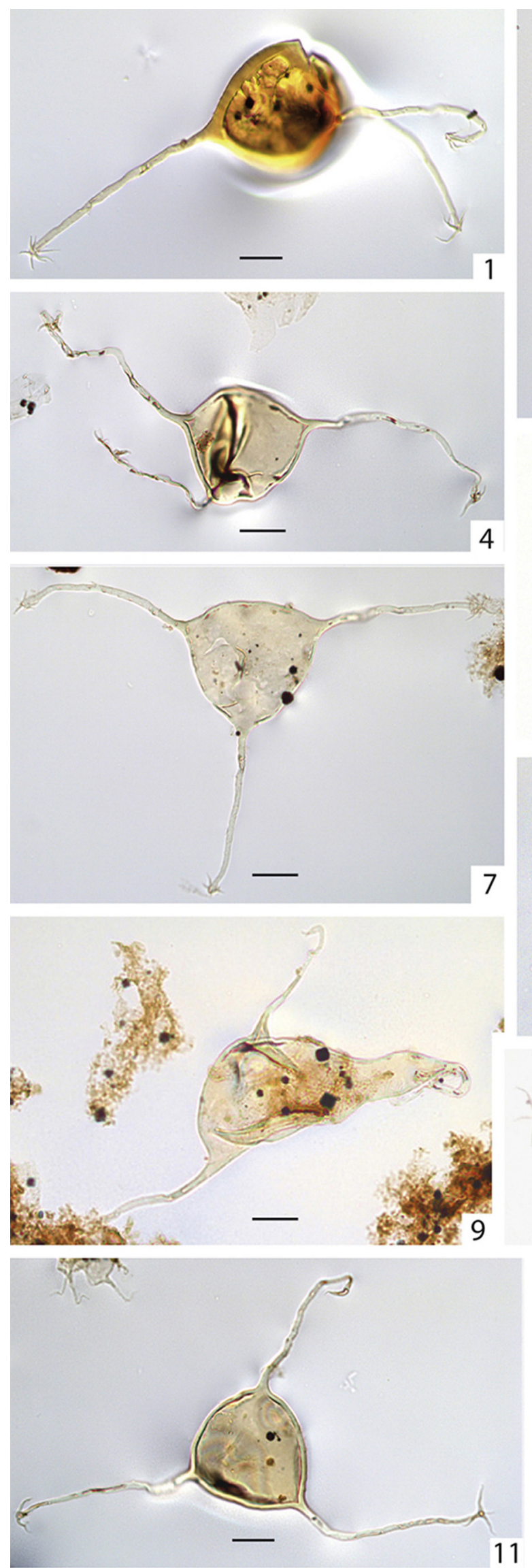
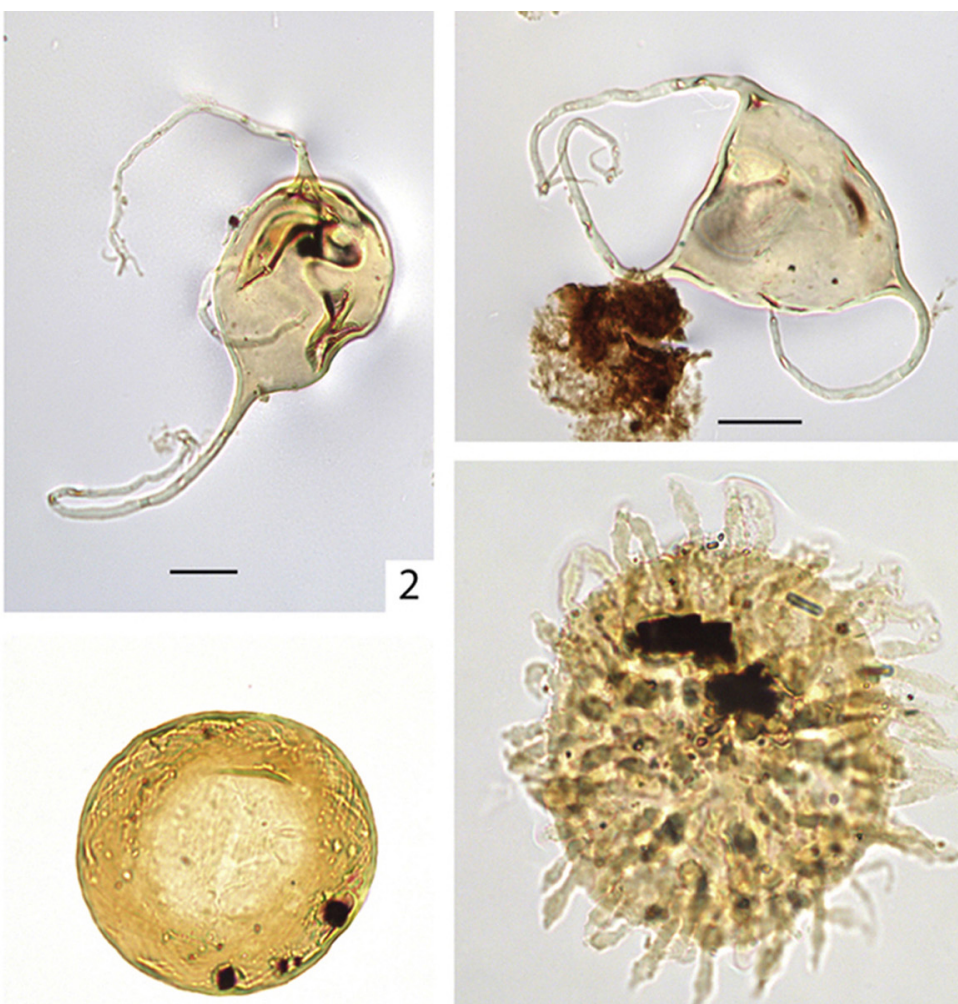

3

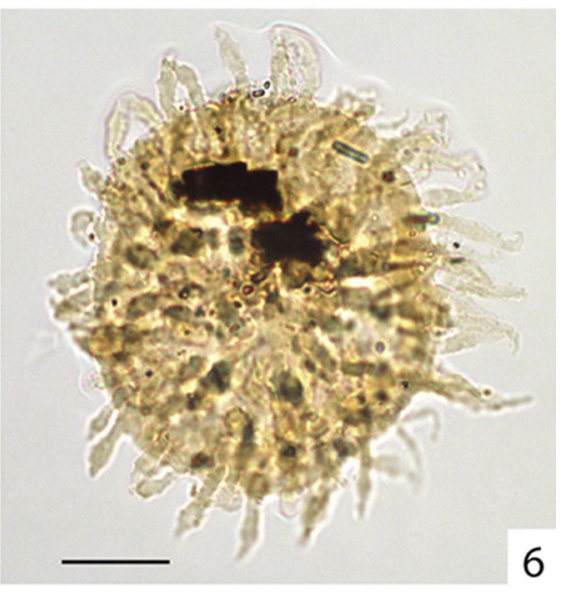

5
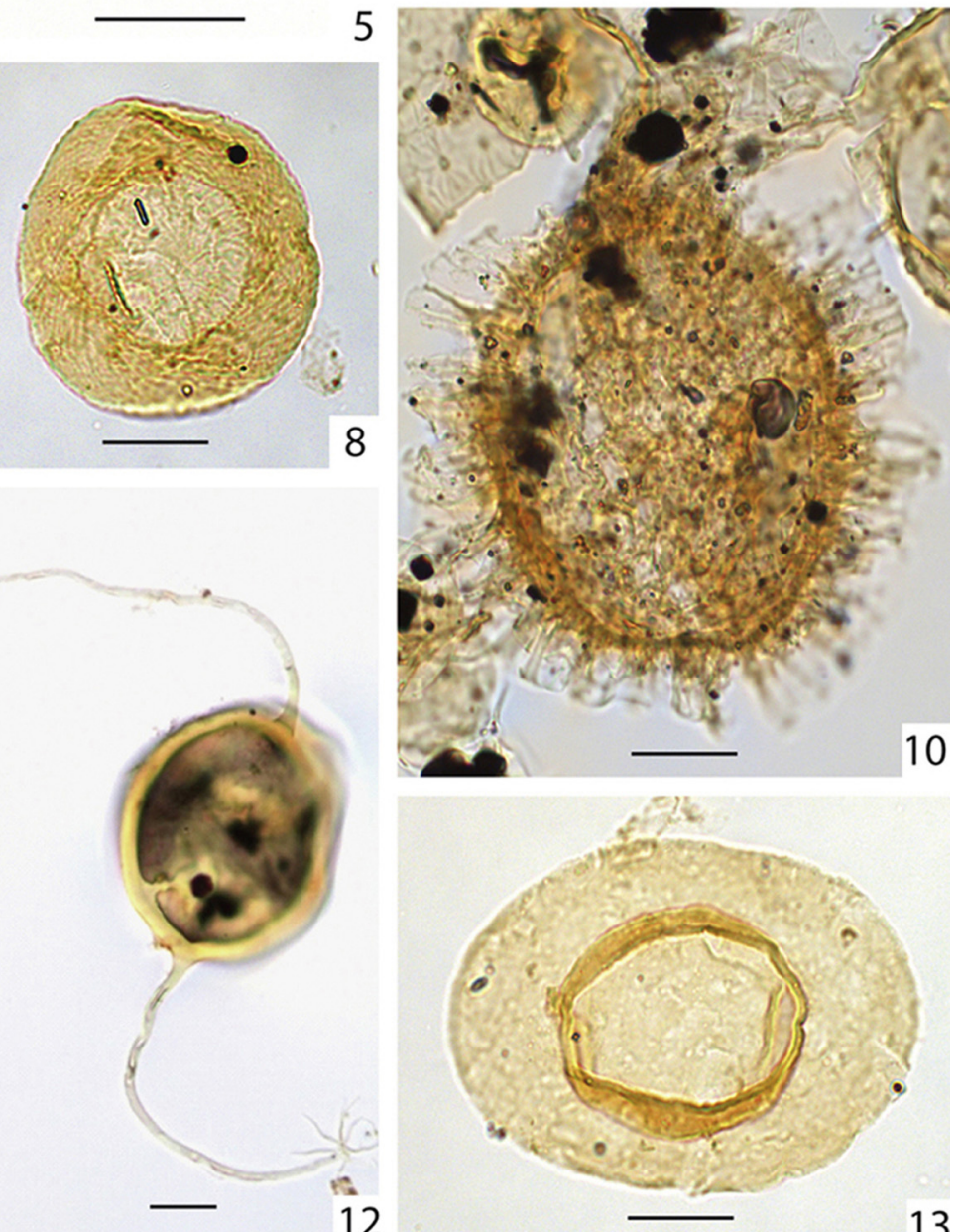
thick-walled vesicle and thin-walled processes may simulate a separation and give impression of a bilayered vesicle. The darker area may extend shortly into the base of the processes". It is evident that with its variable morphology (vesicle of varying thickness and bearing one, two, or three processes), Lusatia dendroidea shows some analogies with Frankea longiuscula var. darriwilense. Lusatia heteromorpha of Vavrdová, 1986, described from the lower Llanvirn of the Prague Basin, differs by capitate terminations of pinnae and a granular central body.

Another possible comparison, based on character variability, is with the Lower to Middle Ordovician genus Dicrodiacrodium, characterized by variability in the presence of an apical process, which can either be plugged at its base or freely communicating with the central body (Servais et al., 1996).

Previous records. The material of Burmann (1970) comes from supposedly upper Llanvirn sediments in eastern Germany. In Cis-Sahara Morocco, Frankea (Multiplicisphaeridium) longiuscula was recorded in the Tadla Basin by Cramer and Diez (1977) from strata attributed to the late Dapingian to Darriwilian based on chitinozoans (Soufiane and Achab, 1993). Possibly, the North African specimens illustrated by Vecoli et al. (1999a, b) can be considered to belong to F. longiuscula var. darriwilense, taking into account the break seen in basal part of some processes, suggesting the existence of a basal thickening. The material of Vecoli et al. (1999a, b) is from the Didymograptus murchisoni graptolite Zone, supporting an early to mid-Darriwilian age (Zalasiewicz et al., 2009), which is consistent with the distribution of $F$. longiuscula darriwilense in QSIM-801.

Occurrence. Uppermost part of the Saq Formation and Hanadir Member of the Qasim Formation in borehole QSIM801, late-early to late Darriwilian.

Genus Micrhystridium Deflandre, 1937

Type species. Micrhystridium inconspicuum (Deflandre 1937) Deflandre 1937 by original designation.

Remark. We concur with other authors in considering Sarjeant and Santcliffe's (1994, p. 22-23) emendation of Micrhystridium, as too broad and impractical. According to currently accepted definitions, Micrhystridium includes small forms of acritarchs, with single-walled spherical to subspherical vesicles, bearing simple acuminated or multifurcated, hollow processes with free communication into vesicle interior.

Micrhystridium regulum sp. nov.

Plate 7, Figs. 2-6

Derivation of name. Latin regulum, petty king, referring to the little size of this species.

Typification. Holotype, QSIM-801 well, core 1, level $749.9 \mathrm{ft}$, slide SA 44891.2 (E61).

Type locality and horizon. QSIM-801 borehole, central Saudi Arabia, Uppermost Saq Formation and Hanadir Member of the Qasim Formation, late-early to late Darriwilian.

Diagnosis. Vesicle originally spherical, outline circular to subcircular, distinct from processes. Wall single layered, $0.5 \mu \mathrm{m}$ thick, psilate. Between 7 to 12 homormorphic processes, cylindrical, quite large, clearly differentiated from the vesicle cavity and with angular contact; wall psilate, tapering to acuminate tips. Excystment structure not observed.

Remarks and comparison. Micrhystridium regulum sp. nov. is characterized by processes of variable shape, size and number. Two morphotypes are distinguished: one with short processes, occurring mainly in the Saq Formation; the second bearing longer processes and occurring in the Hanadir Member of the Qasim Formation. Among the different species of Micrhystridium recorded in this material, many have simple morphology and are difficult to assign to established unornamented species based on variation involving only size, length and number of simple processes. The species Micrhystridium regulum is unique, and in spite of its small size, is easy to distinguish in optical view and SEM from other species of Micrhystridium.

Dimensions. Vesicle diameter, 3-6.5 $\mu \mathrm{m}$; length of processes, 1.5 to $5.5 \mu \mathrm{m}$ (ca.10 specimens measured).

Occurrence. Uppermost part of the Saq Formation, and Hanadir Shale Member of the Qasim Formation in QSIM-801 well, Acritarch Zones 2 and 3, late-early to late Darriwilian.

Genus Tyrannus Wood and Tekbali, 1987

Type species. Tyrannus giganteus (Jardiné et al., 1974) Wood and Tekbali, 1987

\footnotetext{
Plate 3. Acritarchs and sporomorphs from QSIM-801 Well, Saudi Arabia. Key to abbreviations: SA, Saudi Aramco collection; LPB, Laboratory of Paleontology of Brest collection; EF, England Finder coordinates. Scale bar $20 \mu \mathrm{m}$ for all figured specimens. Figs. 1-4, 7, 9, 11-12. Frankea longiuscula var. darriwilense var. nov. Fig. 1: $686.6 \mathrm{ft}$, slide SA 44851 (EF P47/2); diameter of central body, $55 \mu \mathrm{m}$; length of processes, $78 \mu \mathrm{m}$; length of pinnae, $6-7 \mu \mathrm{m}$; one process showing bulbous tip and single pinna. Fig. 2: $715.6 \mathrm{ft}$, slide SA 44861.2 (EF P49/3), specimen with subcircular central body; diameter of central body, $56 \mu \mathrm{m}$; length of processes, $90 \mu \mathrm{m}$; two processes bear 4-5 pinnae, the third one is incomplete. Fig. 3: $715.6 \mathrm{ft}$, slide SA 44861.2 (EF N48); diameter of central body, $55 \mu \mathrm{m}$; length of processes, $72 \mu \mathrm{m}$; one process is simple, the others bear 3-4 pinnae. Fig. 4: 699.9 ft, slide SA 44857.2 (EF S59); diameter of central body, $49 \mu \mathrm{m}$; length of processes, $78 \mu \mathrm{m}$; processes bear 3-4 pinnae. Fig. 7: 715.6 ft, slide SA 44861.2 (EF S48/1), Holotype showing subtriangular central body and epithyche ("horse-shoe" opening); diameter of subtriangular central body, $55 \mu \mathrm{m}$; length of processes, $78 \mu \mathrm{m}$; number of pinnae 4-5 pinnae. Fig. 9: $746.5 \mathrm{ft}$, slide SA 44890 (EF G51), aberrant specimen with subtriangular central body; diameter of central body, $40 \mu \mathrm{m}$, showing an expansion up to $86 \mu \mathrm{m}$ in length at right corner; the tips of two visible processes are slightly bulbous with a single distal pinna. Fig. 11: $675.1 \mathrm{ft}$, slide SA 44853.2 (EF R56/4), specimen showing one process with bulbous tip and single pinna; diameter of central body, $55 \mu \mathrm{m}$; length of processes, $78 \mu \mathrm{m}$; length of pinnae, 6-7 $\mu \mathrm{m}$. Fig. 12: 675.1 ft, slide SA 44853.2 (EF U51/1), bipolar-symmetric specimen with rounded vesicle and bearing only two processes; dimensions of central body, $55 \times 48 \mu \mathrm{m}$; length of processes, $78 \mu \mathrm{m}$; number of pinnae, 3 to 6 ; length of pinnae, up to $8 \mu \mathrm{m}$. Figs. 5, 8. Hilate Sporomorphs 1. Fig. 5: $728.5 \mathrm{ft}$, slide SA 44883.2 (EF K55/2); diameter of vesicle, $33 \mu \mathrm{m}$; diameter of central pylome, $18 \mu \mathrm{m}$. Fig. 8: $756 \mathrm{ft}$, slide SA 44894.2 (EF T58/1); diameter of vesicle, $37 \mu \mathrm{m}$; diameter of central pylome, $10 \mu \mathrm{m}$. Fig. 6. Indeterminate sp. A. $728.5 \mathrm{ft}$, slide SA 44883.2 (EF J53); diameter of vesicle, $50 \mu \mathrm{m}$; length of processes, 8-9 $\mu \mathrm{m}$. Fig. 10. Aremoricanium aff. A. decoratum Loeblich and Mc Adam, 1971. $728.5 \mathrm{ft}$, slide LPB 13076 (EF H33/2); diameter of vesicle, $55 \times 48 \mu \mathrm{m}$; length of tubular neck-like extension, $20 \mu \mathrm{m}$; length of processes, 11-13 $\mu \mathrm{m}$. Fig. 13. Pterospermopsis francinae Quintavalle and Playford (2006a, b). $728.5 \mathrm{ft}$, slide SA 44883.2 (EF J58/2); diameter of the central body, $26 \mu \mathrm{m}$; overall diameter including flange, $42-53 \mu \mathrm{m}$.
} 

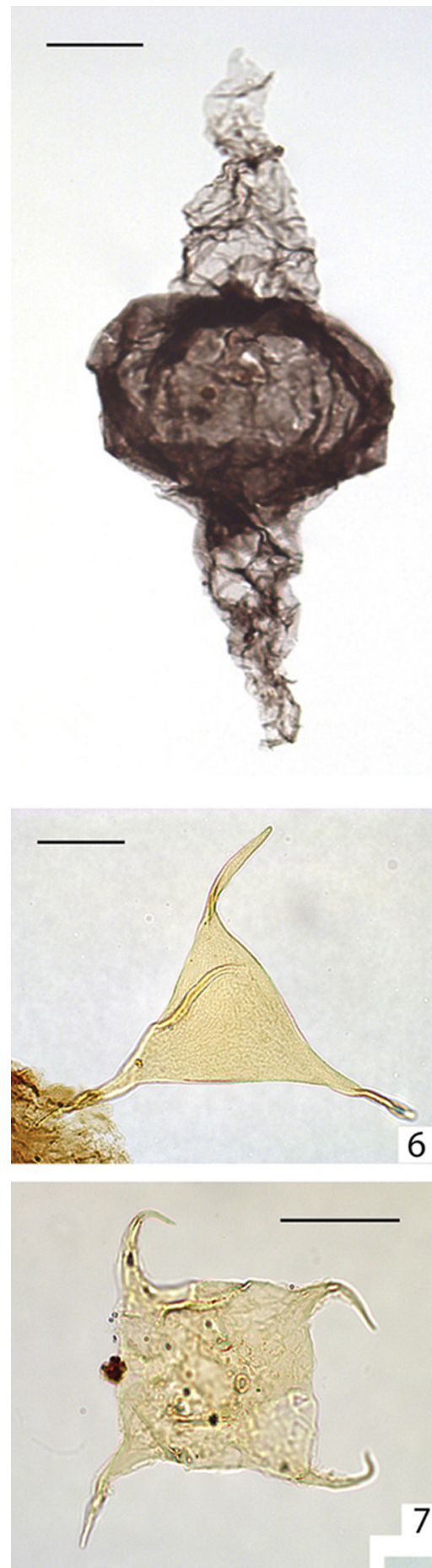

6
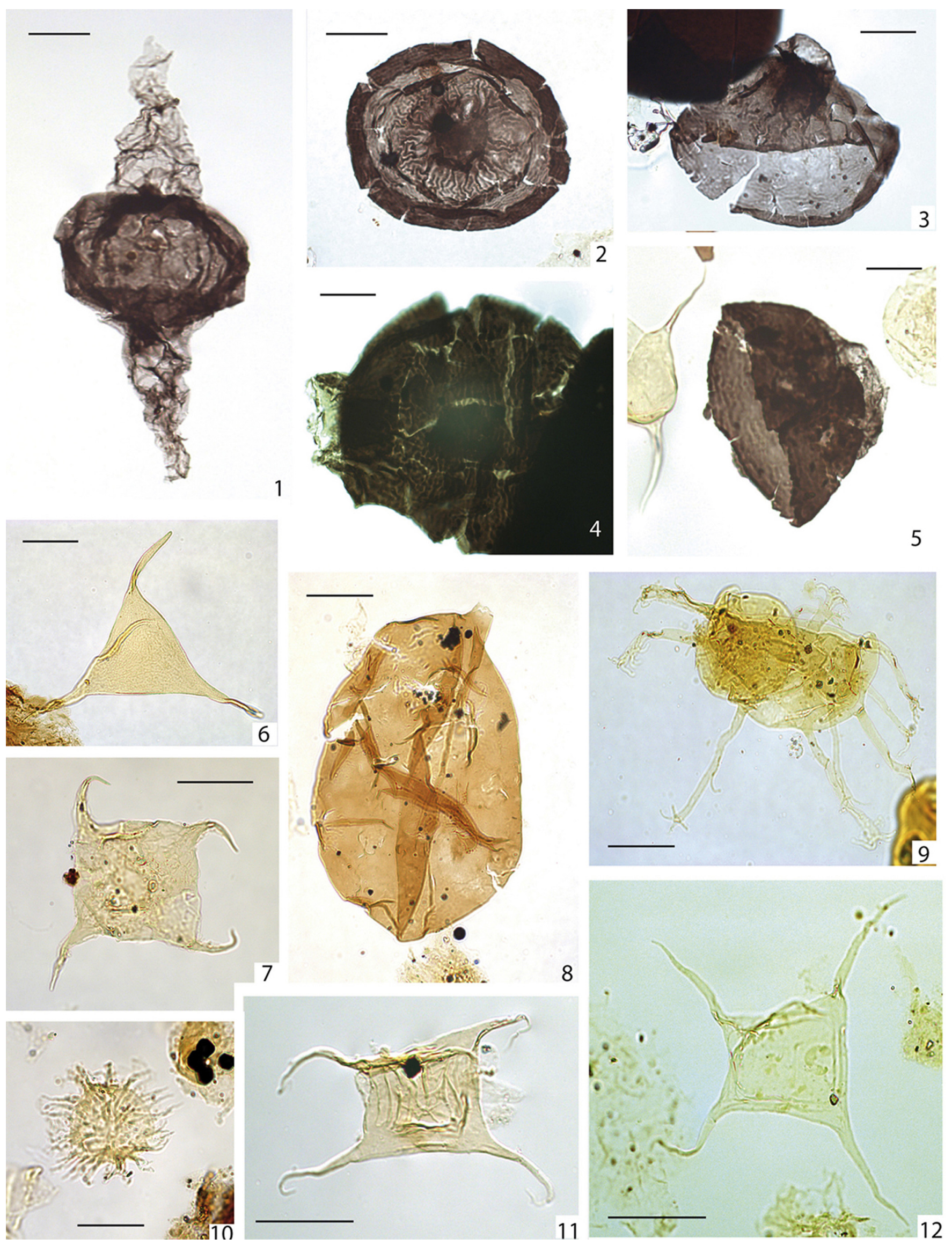
Tyrannus proteus sp. nov.

Plate 5, Figs. 1-13.

2007 Tyrannus sp. A, Le Hérissé, Al-Ruwaili, Miller, Vecoli, p. 12, Plate 2, figs. 1, 2, 4.

Derivation of name. Latin proteus, proteiform, in reference to the variable aspect of the specimens referred to this species.

Typification. Holotype, QSIM-801 well, level $693.1 \mathrm{ft}$, core 2, slide SA 44853.2, (EF U47/2), Plate 5, Fig. 11.

Type locality and Horizon. Borehole QSIM-801, Central Saudi Arabia, Hanadir Shale Member of the Qasim Formation, middle to late Darriwilian.

Diagnosis. Vesicle hollow, wall thick, unilayered, surface psilate, subtriangular to subcircular or subpolygonal in outline, depending on the numbers of processes. Two to eight processes, cylindrical to conical, hollow, communicating freely with the central cavity, distally truncate and open. The distal extremities of the processes appear to be thinner and lighter in color.

Dimensions. Vesicle diameter, $75-125 \mu \mathrm{m}$; process length, 25 to $50 \mu \mathrm{m}$; process width, $10-15 \mu \mathrm{m}$; overall diameter 90-200 $\mu \mathrm{m}$ (ca. 100 specimens measured).

Remarks. Considering the previously described specimens (Le Hérissé et al., 2007) many specimens of T. proteus sp. nov. has been observed and studied from QSIM-801, in optical view, SEM and using CLSM. In order to test the hypothesis that T. proteus could occur in clusters of interconnected specimens, the new specimens were recovered from QSIM-801 samples using a low-impact preparation procedure, which avoids the use of centrifugation, oxidation and further manipulation for the separation of heavy minerals,. However, no such clusters were recovered, and our findings confirm that Tyrannus proteus sp. nov. possesses all the features of a unicellular organism, such as a vegetative cell, a cyst stage or a spore.

The generic attribution to Tyrannus is based on the following important characteristics of this taxon: a) large size, b) pigmentation of the vesicle resulting in the characteristic light brown coloration, c) distally open processes. Unlike the majority of the acritarch species observed in the assemblages (with the sole exception of Frankea longiuscula var. darriwillense), T. proteus is characterized by high morphological variability and polymorphism. This is mostly expressed in the variable vesicle shape and number of processes, while the overall dimensions are remarkably consistent.

CLSM analyses conducted on single specimens also showed major differences in fluorescence intensity between specimens of Stelliferidium and Frankea on the one hand, and T. proteus on the other; these differences cannot be ascribed to differences in thermal alteration and corroborate the idea that $T$. proteus differs in biological affinity from the general acritarch populations of the studied samples.

The general shape, presence of distally open processes, and morphological polymorphism of $T$. proteus are comparable to those observed in the Neoproterozoic palynomorphs Tappania and Germinosphaera, which have been described as possible fungi (Butterfield et al., 1994; Butterfield, 2009). However, no evidence of hypal fusion (e.g., interconnected specimens) has been confirmed in the numerous isolated specimens of T. proteus observed in this study and we can conclude there is no real evidence here that points to fungal affinity for this acritarch.

Occurrence and distribution. The species first occur sparsely in the uppermost part of the Sajir Member of the Saq Formation, and becomes common in the Hanadir Shale Member of the Qasim Formation (Acritarch Zones 2 and 3, late-early to late Darriwilian).

\subsection{Unidentified dark-grey elements}

Organic-walled microfossils which cannot be attributed to any classes of known palynomorphs occur in many of the studied samples. They are of relatively small size (ca. 50 microns), have a spherical, hemispherical, or bipolar symmetry, thin-walled and characteristically dark grey in color, vaguely reminiscent of carbonized woody material. However, these elements do not show the characteristics of charcoal fragments such as splintery fractures, silky lustre or specific internal anatomy (e.g., Scott, 1989, 2010). The most reliable taxonomic feature of this material is its light grey to dark grey color when accompanying acritarchs, prasinophycean algae and cryptospores are continuously pale and light yellow in color, indicating no evidence of thermal alteration in this material. The darkening of the light grey to dark grey material could also be derived from the prolonged transport of continental

Plate 4. Acritarchs and other enigmatic palynomorphs from QSIM-801 Well, Saudi Arabia. Key to abbreviations: SA, Saudi Aramco collection; LPB, Laboratory of Paleontology of Brest collection; EF, England Finder coordinates. Scale bar $20 \mu \mathrm{m}$ for all figured specimens. Figs. 1-5. Dark grey elements. Fig. 1: "Type 1", 699.9 ft, slide SA 44857.2 (EF W56/2); diameter of central body $60 \mu \mathrm{m}$; length of the thin tubular polar extension, 39-78 $\mu \mathrm{m}$. Fig. 2: $741.5 \mathrm{ft}$, slide SA 44888 (EF J51/3), "Type 2", a detached hemi-vesicle seen by the interior and showing radial striae in the polar area; diameter of vesicle, $69 \mu \mathrm{m}$. Fig. 3: $741.5 \mathrm{ft}$, slide SA 44888 (EF V44/2), a detached, conical hemi-vesicle showing a rounded structure in the apical area; diameter of vesicle, $78 \mu \mathrm{m}$; length of vesicle, $35 \mu \mathrm{m}$, diameter of the polar structure, $15 \mu \mathrm{m}$. Fig. 4: $741.5 \mathrm{ft}$, slide SA 44888 (EF G41/4), "Type 2", a complete specimen with the two halves attached, showing a short membranous extension at polar extremities; total length, $90 \mu \mathrm{m}$. Fig. 5: $719.9 \mathrm{ft}$, slide SA 44881.2 (EF Q58/1), "Type 2", a detached hemi-vesicle, showing an ornamentation of concentric granular ridges towards the equatorial zone; total diameter of vesicle, $75 \mu \mathrm{m}$. Fig. 6. Arkonia sp. A Vecoli, 1999. 756 ft, slide SA 44894.2 (EF R54/3); diameter of vesicle, $35 \mu \mathrm{m}$; length of processes, $30 \mu \mathrm{m}$. Fig. 7. Aureotesta clathrata (Vavrdovà) emend. Brocke et al., 1997. $754.8 \mathrm{ft}$, slide LPB 13077 (EF C36/1); diameter of vesicle, $33 \mu \mathrm{m}$; length of processes, 13-14 $\mu \mathrm{m}$. Fig. 8. Ampullula suetica Righi, 1991. $756 \mathrm{ft}$, slide SA 44894.2 (EF R47/4); diameter of vesicle, 61-100 $\mu \mathrm{m}$; length of tubular extension, $8 \mu \mathrm{m}$ (incomplete); diameter of pylome (indicated by arrow), $18 \mu \mathrm{m}$. Fig. 9. Ankyrotrochos crispum (Vavrdovà) Vecoli, 1999. $756 \mathrm{ft}$, slide SA 44894.2 (EF N42/1); diameter of vesicle, $45 \mu \mathrm{m}$; length of processes, 30-35 $\mu \mathrm{m}$. Fig. 10. Comasphaeridium aff. C. pratulum Cramer and Diez, 1974. $754.8 \mathrm{ft}$, slide LPB 13077 (EF C36/1); diameter of vesicle, $33 \mu \mathrm{m}$; length of processes, 13-14 $\mu \mathrm{m}$. Fig. 11. Striatotheca rarirrugulata (Cramer, Kanes, Diez and Christopher) Eisenack, Cramer and Diez, 1976. 682.2 ft, slide SA 44850 (EF W51.4); diameter of vesicle, $24.5 \mu \mathrm{m}$; length of processes, $22 \mu \mathrm{m}$. Fig. 12. Striatotheca monorugulata Yin et al., 1998. $756 \mathrm{ft}$, SA 44894.2 (EF H49/3); dimensions of vesicle, $22 \times 26 \mu \mathrm{m}$; length of processes, $33 \mu \mathrm{m}$. 

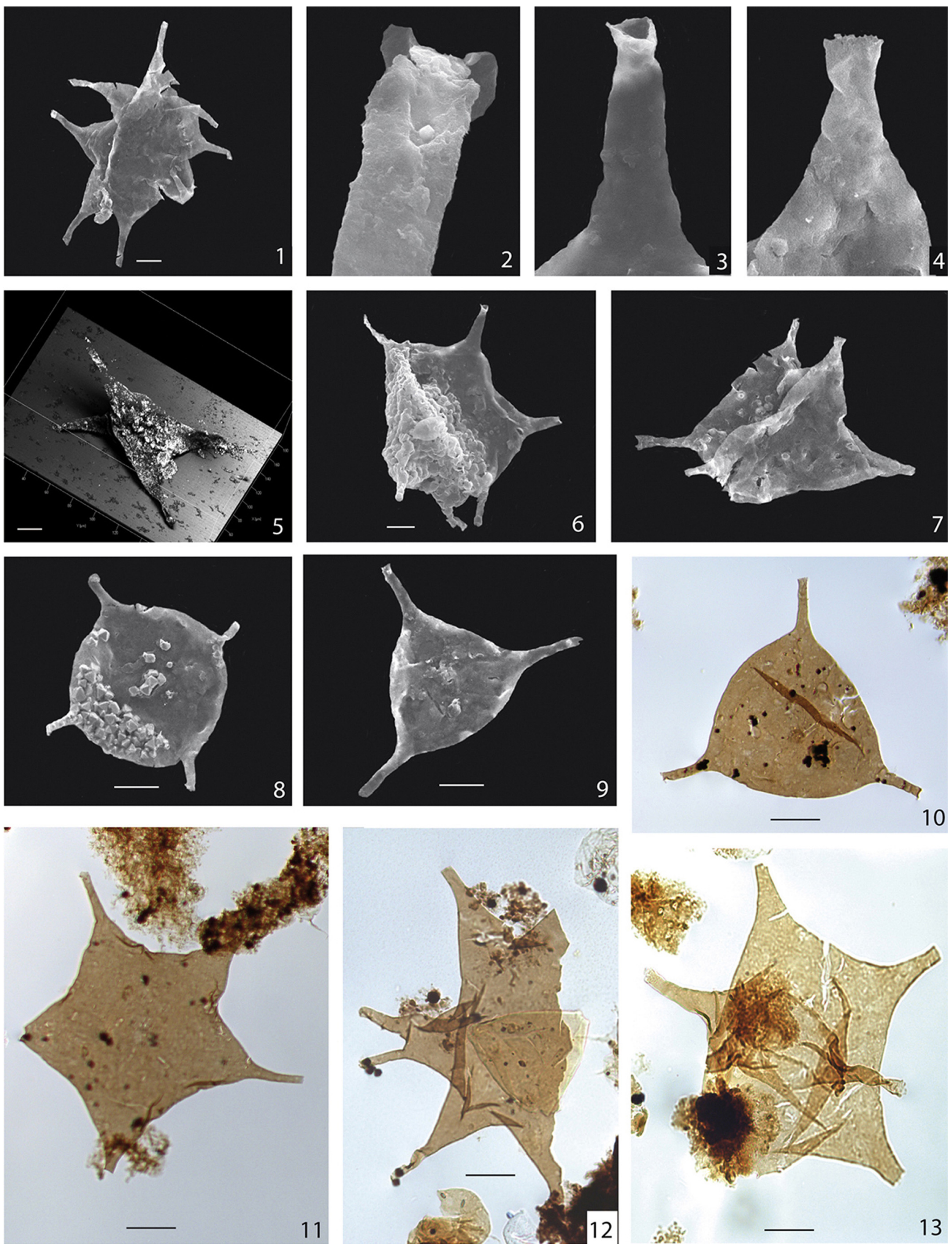
or freshwater material in the marine environment, under possible oxydating conditions. But, as previously mentioned, post-depositional alteration does not seem to have affected any other palynomorphs in the assemblage. Another hypothesis associates these palynomorphs with sediment reworking, which does exist for acritarchs at some levels in the core. But there is no evidence of reworked acritarchs in 37 of the 42 levels where the light grey to dark grey elements occur. Two main morphological types have been recognized, as described below.

\section{Dark-grey element, Type 1}

Plate 4, Fig. 1

Description. Complex palynomorph with bipolar symmetry, composed of a hollow subspherical, dark and relatively thick central body bearing two long, thin-walled membraneous cylindrical extensions drawn out from two opposite polar regions of the central body. These extensions do not communicate with the vesicle cavity. No opening observed.

Dimensions. Diameter of central body, 50-60 $\mu \mathrm{m}$; Length of the membranous polar extensions, 25 to $78 \mu \mathrm{m}$ ( 4 specimens measured).

Discussion and comparison. The presence of tubular extensions on opposite sides of a spherical body is a morphological characteristic shared with the Silurian acritarch Carminella maplewoodensis Cramer, 1964. However, the present specimens differ by a significantly larger size, a thicker and strongly pigmented central body, and by the fact that the tubular extensions are distally closed and not open as in C. maplewoodensis.

\section{Dark-grey element, Type 2}

Plate 4, Figs. 2-5

Description. Palynomorph consisting of two hemispherical halves which are often preserved as detached elements. The outline of the vesicle is circular to oval in polar view. The wall is relatively thick and distinctly pigmented, dark-grey in color. The polar areas are characterized by the presence of a circular thickening surrounded by irregular radial striae. Occasionally, the polar areas bear a thin, short, distally open apical membraneous extension. The equatorial areas are characterized by distinct concentric ridges which are formed either by continuous striae or by the alignment of granular elements.
Dimensions. Complete specimens $45 \times 90 \mu \mathrm{m}$ to $70 \times 100 \mu \mathrm{m}$ in total length and width; isolated halves 69 to $80 \mu \mathrm{m}$ in diameter.

Remark. Many specimens of Type 2 have been recorded only as detached halves.

Discussion and comparison. These specimens resemble the early Devonian acritarch Riculasphaera fissa Loeblich and Tappan, 1969, with the mode of opening by equatorial splitting, but polar ornamentation and sculpture are different. Some similarity exists also with some modern freshwater algal spores, such as Gelasinicysta among the Zygnemataceae, that are spheroidal to discoidal and composed of two equal halves separated by an equatorial suture (Head, 1992).

\section{Composition of palynomorph assemblages}

The samples contain rich and generally well-preserved assemblages of marine palynomorphs (acritarchs, prasinophycean phycomata, chitinozoa), mixed with possible freshwater algae (various sphaeromorphs), and terrestrial elements (cryptospores, described in Steemans et al., present issue). Other problematic palynomorphs (e.g., the dark-grey elements) are more difficult to interpret in terms of paleoenvironmental conditions. We also describe abundant, very small microfossils (picoplanktonic and ultraplanktonic size classes), and we discuss their depositional distribution and paleobiologcial significance.

A total of 72 palynomorphs species, attributed to 37 genera have been identified (Fig. 3). Their distribution forms the basis for a biozonation through the Saq/Hanadir transitional beds, and the associations are compared to coeval assemblages described from elsewhere. Variations in the relative abundance of marine and terrestrial palynomorph, are analyzed quantitatively, together with fluctuations in abundance of AOM and these variations are interpreted in terms of paleoenvironmental changes along the section (Figs. 4 and 5).

\subsection{Biozonation}

Among the acritarchs and prasinophycean phycomata assemblages in the QSIM-801 section, the presence of Arkonia, Frankea and Striatotheca clearly indicates affinities with the temperate to cold Mediterranean (or Perigondwana) Province (Molyneux et al., 2013). Even if no direct relationship between

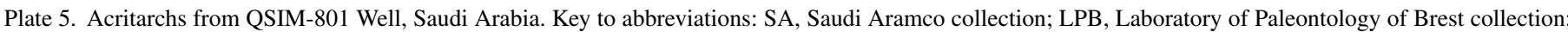

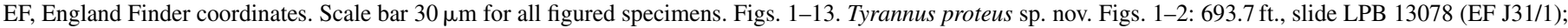

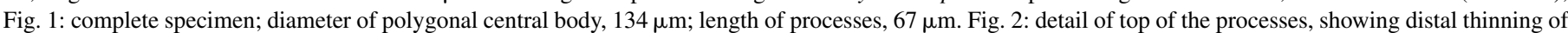

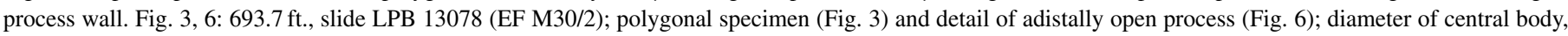

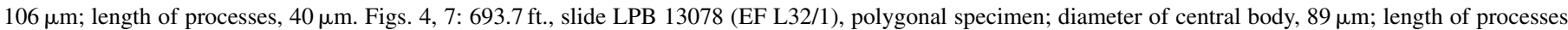

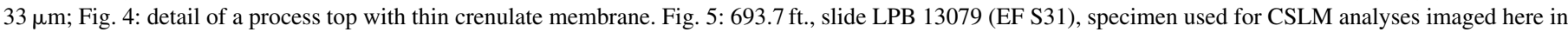

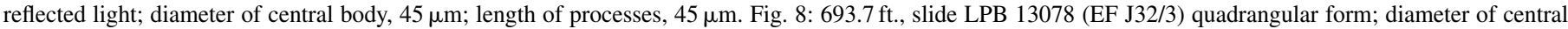

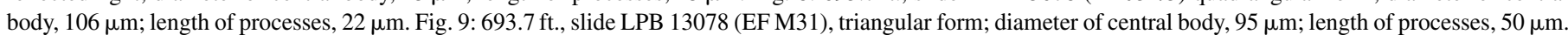

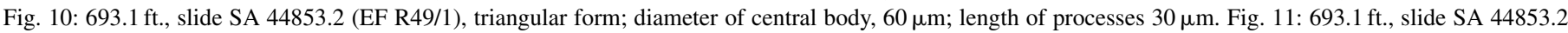

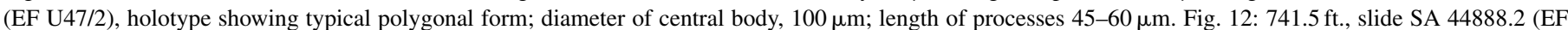

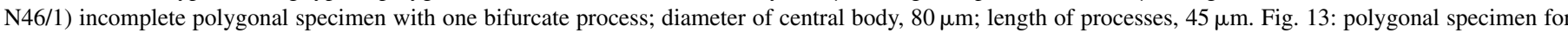

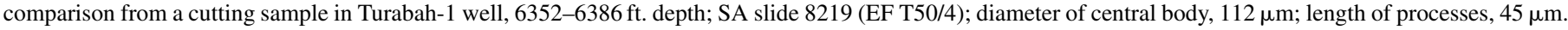



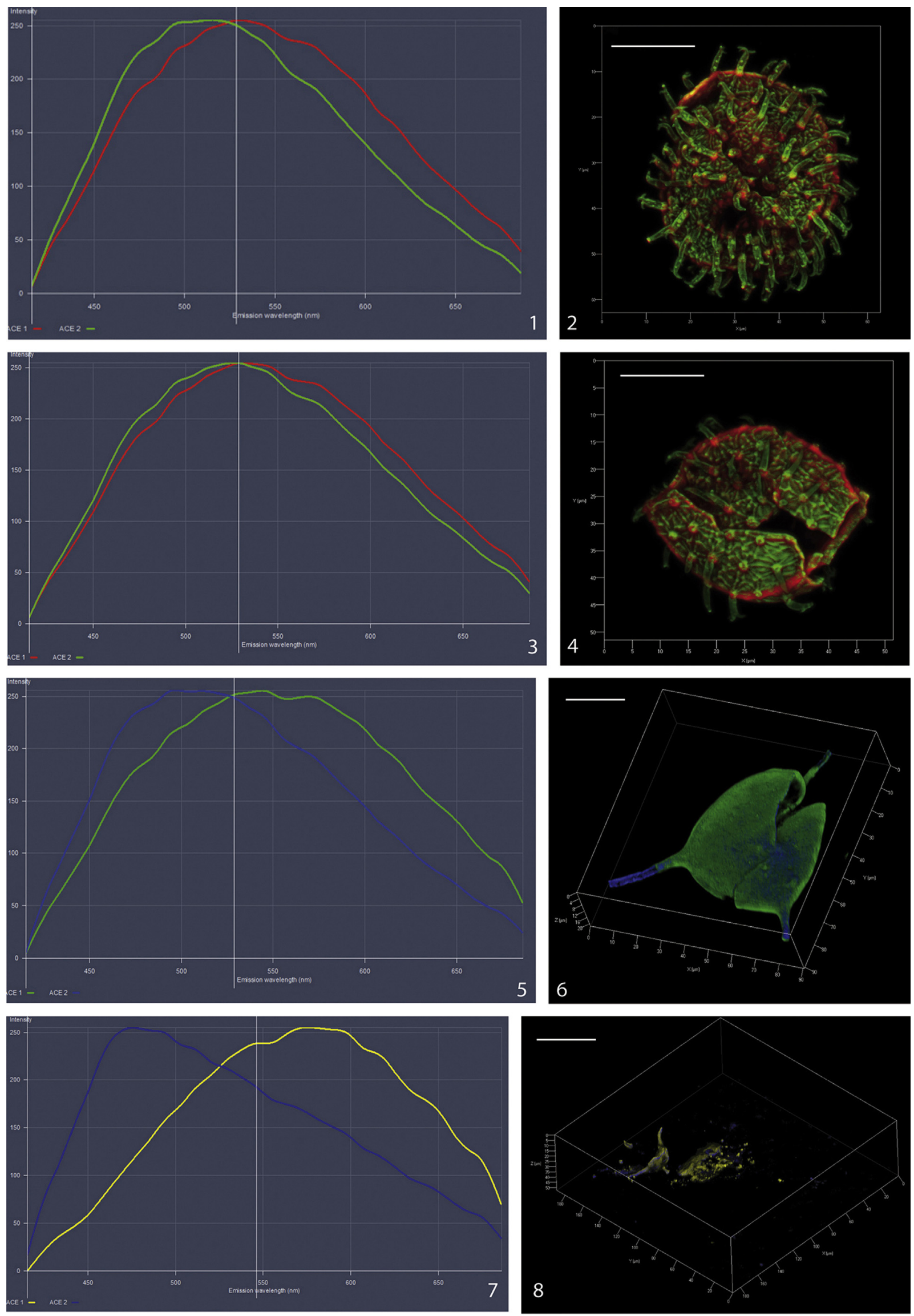
acritarch biogeography and paleolatitude and/or climatic belts can be demonstrated (Molyneux et al., 2013), the distribution of certain genera, such as Frankea, seems restricted to areas of high paleolatitudes, characterized by cold water masses (Colbath, 1990; Tongiorgi et al., 1995; Vecoli et al., 1999a, b).

Based on the distribution of the palynomorphs (Fig. 4), the sequence of Saq/Hanadir transitional beds in QSIM-801, can be divided into 3 main intervals, defined by Assemblage Zones 1 to 3 . The changes in the composition of palynomorph assemblages and the biostratigraphic events recorded, such as the First Appearance Datum (FAD), the Last Appearance Datum (LAD) and acme events are certainly partially controlled by local environmental conditions. Some inconsistencies in the stratigraphical ranges of important taxa found elsewhere may be explained by sediment reworking.

In the following discussion, only the biostratigraphically important taxa which are used to identify zones or sub-zones are cited. Many other accessory taxa are present (Fig. 4), but these are not discussed because of their limited biostratigraphic value.

\subsubsection{Assemblage Zone 1}

The stratigraphically lowermost assemblage occurs from 767.8 to $762.3 \mathrm{ft}$ (Core 8), in the Sajir Member of the Saq Formation. It shows a predominance of prasinophytes represented by leiospheres of variable diameter, clusters of small sphaeromorphs and some enigmatic striate sphaeromorphs; acritarchs are little diversified and chitinozoa are poorly represented; the first occurrence of the enigmatic dark grey elements is also recorded in this assemblage zone. Among the acritarchs, rare Aremoricanium rigaudae, Arkonia sp. A, Aureotesta clathrata, Dicrodiacrodium ancoriforme, Comasphaeridium aff. C. piluliferum, Frankea breviuscula, F. longiuscula, Michystridium spp., Polygonium spp., Stellechinatum celestum, together with few galeate and veryhachid acritarchs, are recorded.

Most of these taxa, especially at genus level (e.g., Dicrodiacrodium, Frankea, Aremoricanium) have been recorded worldwide from strata ranging in age from late Dapingian to Darriwilian stages of the Middle Ordovician Series (Brocke et al., 1995; Vecoli and Le Hérissé, 2004; Li et al., 2010). However, the age of the present assemblage seems to be restricted to the earliest Darriwilian, based on the following considerations:
- presence of Arkonia sp. A, a species described in the Ghadamis Basin in North Africa in an assemblages attributed to the Darriwilian (Vecoli, 1999). Moreover, according to Servais (1997), the first occurrence of Arkonia is in the British D. hirundo graptolite Zone, of latest Arenig age, i.e. early Darriwilian, equivalent of the $U$. austrodentatus graptolite zone of South China;

- presence of Frankea longiuscula; a species normally considered indicative of a middle Darriwilian or younger age (Vecoli and Le Hérissé, 2004);

- similarities with the acritarch assemblage described from the Saih Nihayda Formation of Oman considered to be of mid to late Darriwilian age (Rickards et al., 2010), notably with the presence of, among others, the distinctive "Hilate sporomorph 1" (Le Hérissé et al., 2007; indicated as "spore indeterminate B in Rickards et al., 2010).

Taking into account the above observations, Assemblage Zone 1 could be considered equivalent to the bulla chitinozoan biozone (lower Darriwilian), which has been previously found in the upper part of the Saq Formation (Paris et al., 2007). This would be also consistent with the presence of the chitinozoan Siphonochitina formosa in Assemblage Zone 2.

The analysis of the relative abundance of the major palynomorph groups yields some paleoenvironmental insights. Cryptospores, which are allochtonous elements introduced into the marine assemblage, make up 3 to $6.5 \%$ of the total palynomorph content. This relatively high abundance of cryptospores, associated with poor representatiion of chitinozoans and low diversity of acritarchs, is consistent with a sand-dominated tidal flat, marginal marine paleoenvironment (shallow shelf-sea), as suggested by the sedimentological analysis.

Representatives of Leiosphaeridia spp. are major components of the assemblages in these transitional strata across the Saq/Hanadir boundary. They occur as separate individuals up to $100 \mu \mathrm{m}$ in diameter (abundance between 43 to $76 \%$ of total palynomorph counts), or in clusters (19 to $42.6 \%$ ). In previous studies, Leiosphaeridia-dominated palynological assemblages have been related to glacio-eustatic sedimentary cycles, in ice marginal environments under seasonal ice and in low salinity and temperature environments in circum-arctic and Antarctic settings (Mudie, 1992, Prebble et al., 2006). High numbers of

Plate 6. Acritarchs from QSIM-801 Well, Saudi Arabia. Key to abbreviations: LPB, Laboratory of Paleontology of Brest collection; EF, England Finder coordinates. Scale bar $20 \mu \mathrm{m}$ for all figured specimens. Figs. 1-4. Stelliferidium striatulum (Vavrdova, 1966) Deunff et al., 1974. Figs. 1, 3: $728.5 \mathrm{ft}$; fluorescent spectral measurements and profiles of two specimens of Stelliferidium striatulum. Profiles in green illustrate excitation spectrum of the thin processes. Red regions and profiles are the emission spectra characteristic of the vesicle wall. The form of the profiles of the two specimens and the fluorescence intensity show remarkable consistency. 2: Stelliferidium striatulum, LPB 13085 (EF H35); vesicle diameter $45 \mu \mathrm{m}$; process length, 10-15 $\mu \mathrm{m}$. 4: Stelliferidium striatulum, LPB13085 (EF P31/3); diameter of vesicle, $36 \mu \mathrm{m}$; length of processes, 10-15 $\mu \mathrm{m}$. Figs. 5, 6. Frankea longiuscula var. darriwilense var. nov. $728.5 \mathrm{ft}$. Fig. 5: variation in fluorescence intensity reflects variation in the thickness of vesicle wall and base of the processes. Profile in green illustrates excitation spectrum of the vesicle; intensity of the emission spectra are similar to those observed in Stelliferidium striatulum. Profile in blue illustrates the emission spectra of the processes, also similar to those observed in Stelliferidium striatulum. Fig. 6: LPB 13085 (EF 043), diameter of vesicle, $50 \mu \mathrm{m}$. Figs. 7, 8. Tyrannus proteus sp. nov. $728.5 \mathrm{ft}$. Fig. 7: fluorescence spectra; the yellow profile (emission spectrum of the vesicle) is very displaced towards the right compared to the one observed in Stelliferidium striatulum or Frankea longiuscula var. darriwilense. The blue profile (emission spectrum of processes) also contrasts with the emission spectra of Stelliferidium and F. longiuscula var darriwilense. Fig. 8: LPB 13085 (EF S31); diameter of vesicle, $45 \mu \mathrm{m}$; length of processes, $45 \mu \mathrm{m}$. 


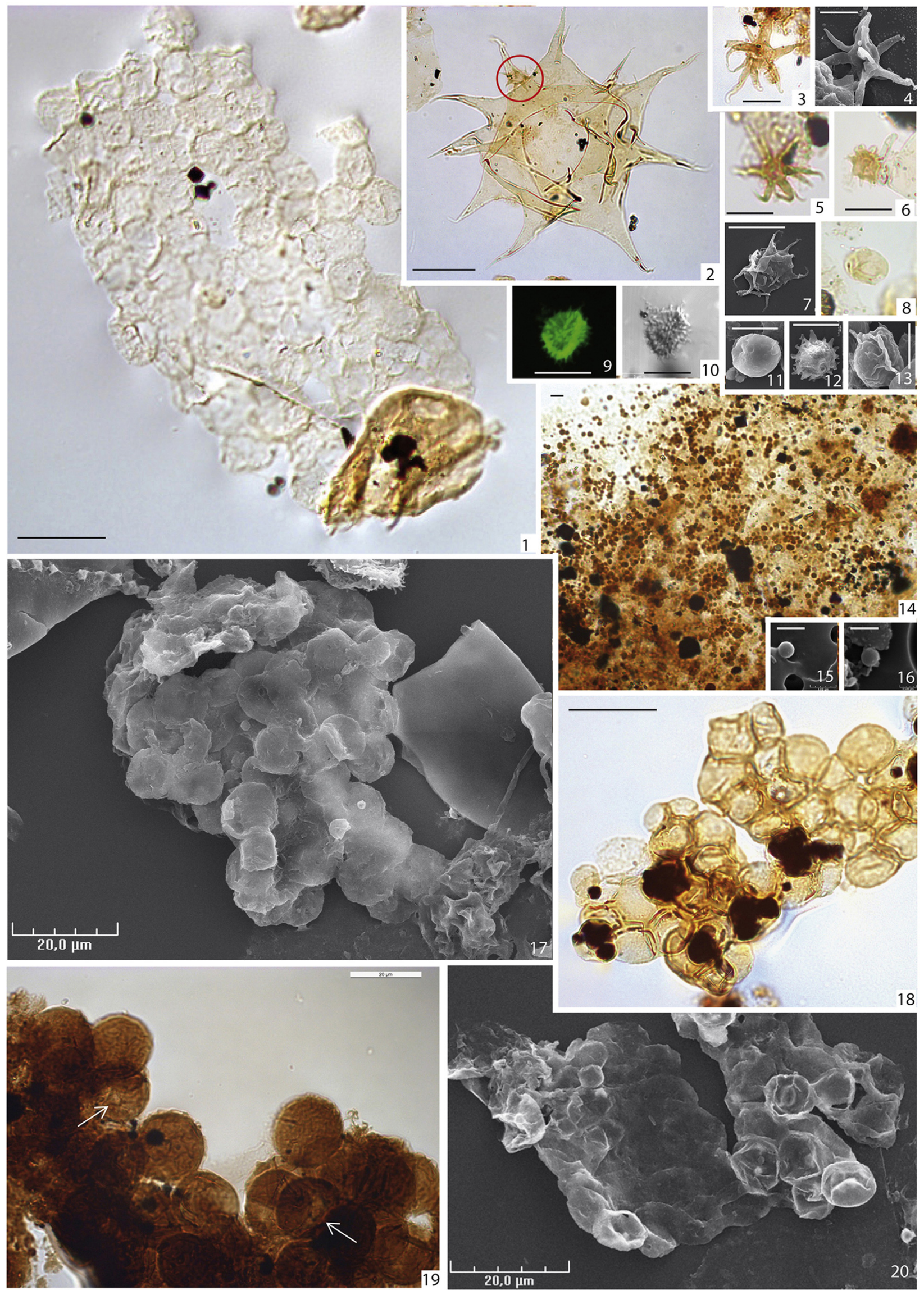




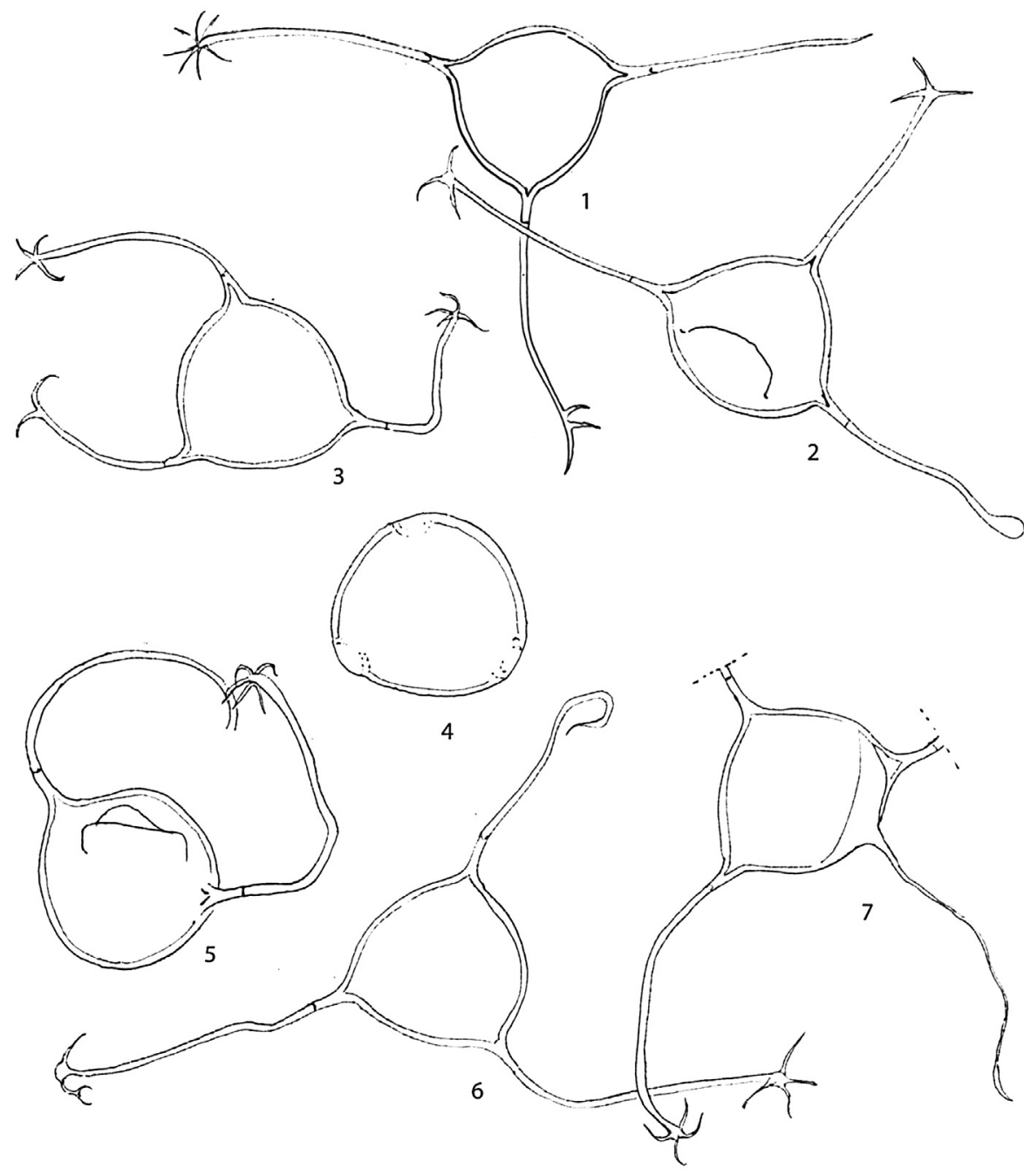

Fig. 2. Morphological variability observed in a population of Frankea longiuscula var. darriwilense. The species is usually characterized by triangular vesicle and three well-developed processes. Morphological polymorphism is especially expressed in the variable process number and shape (form and number of terminal pinnae). Aberrant, or teratological forms are also observed showing bipolar symmetry, presence of additional processes, or rounded vesicle devoid of any process.

leiosphaerids recorded in Triassic sediments of North China have been correlated with highly productive hydrocarbon source rocks (Ji et al., 2008). In the present sequence, the unusually high abundance of these sphaeromorphs (of probable mixed marine and freshwater origin), isolated or in colonies, could be related to the high TOC values (up to $2.98 \%$ ) and possibly be the origin of the abundant type II kerogen found in the Hanadir Shale Member (Ghazwani, 2012).

Plate 7. Acritarchs, coenobia and nannospheres from QSIM-801 Well, Saudi Arabia. Scale bars as follows, Figs. 1, 2, 17-20: $20 \mu \mathrm{m}$; Figs. 3-13: $5 \mu \mathrm{m}$; Figs. 14-16: $1 \mu \mathrm{m}$. Fig. 1. Minute palynomorph cluster, Type 2. $677.9 \mathrm{ft}$, slide SA 44845 (EF H56/3); planar coenobium with cells (78 elements), diameter of each cell, 10-12 $\mu \mathrm{m}$. Fig. 2-6. Micrhystridium regulum sp. nov. Fig. 2: $756 \mathrm{ft}$, slide SA 44894.2 (EF Q54/3), specimen attached to a large Goniosphaeridium sp. Diameter of central body of M. regulum, $4.5 \mu \mathrm{m}$; process length $3.3 \mu \mathrm{m}$; Goniosphaeridium sp., Central body $53 \mu \mathrm{m}$, process length 13.5-28 $\mu \mathrm{m}$. Fig. 3: Micrhystridium regulum sp. nov. $749.9 \mathrm{ft}$, SA 44891.2 (EF E61), holotype; diameter of central body, $4 \mu \mathrm{m}$; length of processes, $4.5 \mu \mathrm{m}$. Fig. $4: 712.7 \mathrm{ft}$, slide LPB 13081 (EF 030/1), SEM view; diameter of central body, $4 \mu \mathrm{m}$; length of processes, $5 \mu \mathrm{m}$. Fig. 5: $682.2 \mathrm{ft}$, slide LPB 13083 (EF G41); diameter of central body, $2.5 \mu \mathrm{m}$; length of processes, 3-3.5 $\mu \mathrm{m}$. Fig. 6: $751.8 \mathrm{ft}$, slide LPB 13084 (EF D43/1); diameter of central body, $4 \mu \mathrm{m}$; length of processes, 1.5-2 $\mu \mathrm{m}$. Fig. 7. Micrhystridium sp. 1. $712.7 \mathrm{ft}$, slide LPB 13081 (EF G33/3); diameter of central body, $4.8 \mu \mathrm{m}$; length of processes, $2 \mu \mathrm{m}$. Fig. 8. Leiosphaeridia sp. $756 \mathrm{ft}$, slide SA 44894.2 (EF F48/3); vesicle diameter, $7 \mu \mathrm{m}$. Figs. 9, 10. Micrhystridium sp. 2. Fig. 9: CLSM view with autofluorescent signal. Fig. 10: $712.7 \mathrm{ft}$, same specimen as Fig. 9, imaged in reflected light; diameter of central body, $5 \mu \mathrm{m}$; length of processes, 1-1.5 $\mu \mathrm{m}$. Fig. 11. Leiosphaeridia sp. $712.7 \mathrm{ft}$, slide LPB 13082 (EF L31/3); vesicle diameter, $6 \mu \mathrm{m}$. Fig. 12 . Micrhystridium sp. 3. $712.7 \mathrm{ft}$, slide LPB 13082 (EF N30/3); diameter of central body, $3 \mu \mathrm{m}$, length of processes, $0.8-1 \mu \mathrm{m}$. Fig. 13. Cymatiosphaera sp. $712.7 \mathrm{ft}$, slide LPB 13082 (EF N30/3); diameter of central body, $6 \mu \mathrm{m}$, height of membranous crest, $3 \mu \mathrm{m}$. Fig. 14. $751.8 \mathrm{ft}$, slide LPB 13079 (EF K33); aggregates of stained nannospheres, 200 to $500 \mathrm{~nm}$ in diameter, associated with decaying organic matter mats. Figs. 15,16 . Nanobacteria on nucleopore polycarbonate filter ( $0.8 \mu \mathrm{m})$, respectively 0.6 and $0.5 \mu \mathrm{m}$ in diameter. $712.7 \mathrm{ft}$, slide LPB 13080. Fig. 17. SEM view of a cluster of densely packed small and mostly laevigate sphaeromorphs. $712.7 \mathrm{ft}$, slide LPB 13082 (EF N32/2); diameter of individual units, 6-10 $\mu \mathrm{m}$. Fig. 18. Cluster of densely packed, laevigate sphaeromorphs, suggesting permanent tetrads. $690.3 \mathrm{ft}$, slide SA 44852.2 (EF G54/4); mean diameter of individual units, $10 \mu \mathrm{m}$. Fig. 19. Minute palynomorph cluster, Type $1.684 \mathrm{ft}$, slide SA 44881.2 (EF F44); loosely packed, non-adherent units, with a pseudoreticulate ornamentation; diameter of cells, 18-20. Some cells show a pylome. Fig. 20. Minute palynomorph cluster, Type 1. $712.7 \mathrm{ft}$, slide LPB 13073 (EF Q31), SEM view showing densely packed cells; diameter of cells, 4.5-9 $\mu \mathrm{m}$. 


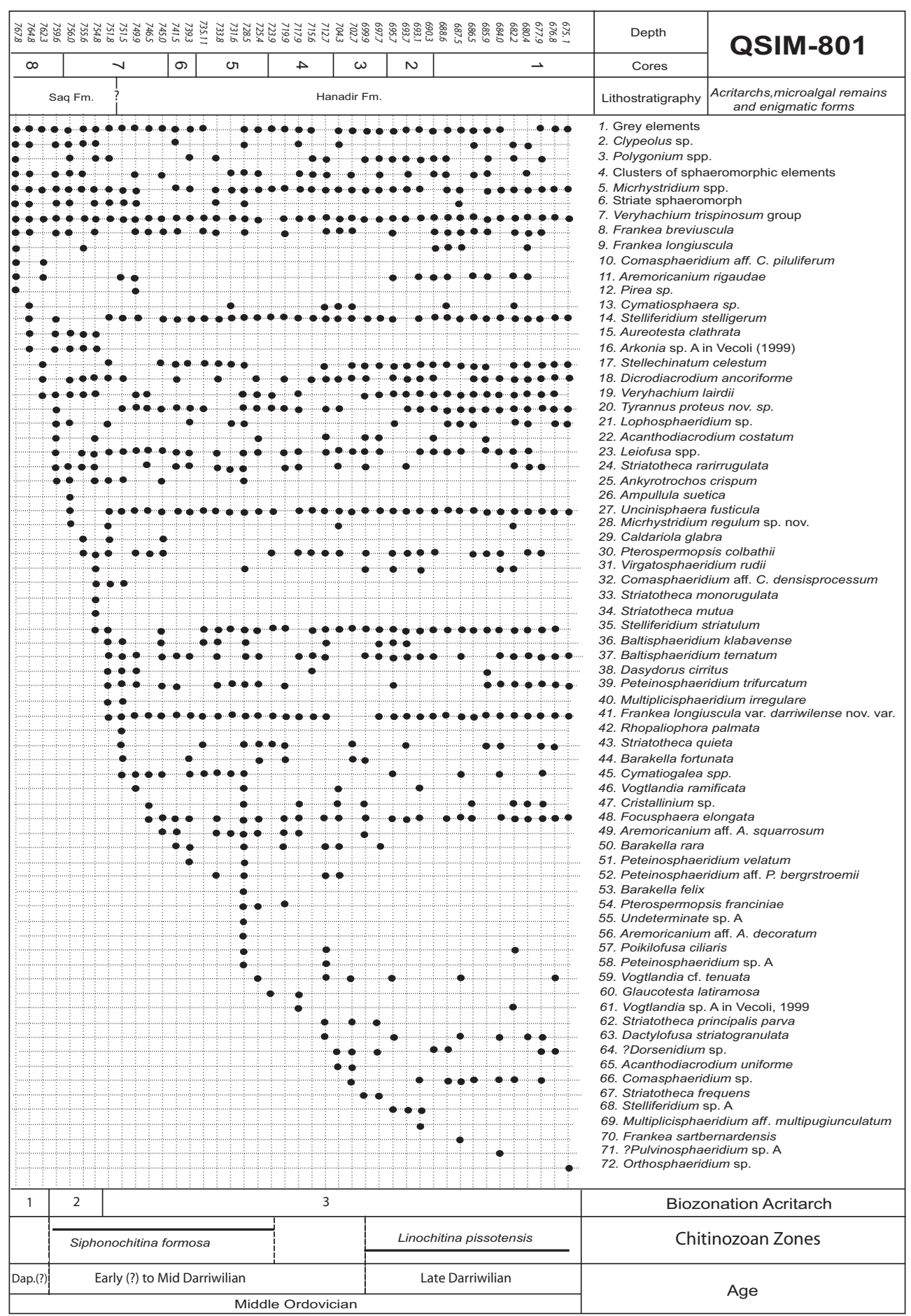

Fig. 3. Stratigraphic range of acritarchs, prasinophycean phycomata and enigmatic forms in the Saq/Hanadir transitional beds, QSIM-801 well, cores 1-8.

\subsubsection{Assemblage Zone 2}

Assemblage Zone 2 is defined in parts of cores 8 and 7, from 759.6 to $754.8 \mathrm{ft}$ in the uppermost Sajir Member of the Saq Formation. A marked increase in both the relative abundance of chitinozoans (from an average of $1.63 \%$ at the top of Assemblage Zone 1 to an average of $21.5 \%$ at the base of Assemblage Zone 2 ), and the diversity of acritarchs, indicates that rapid marine flooding occurred between 762.3 (top of Zone 2) and 759,6 ft.
This is consistent with the observed drop in cryptospore abundance (from $\mathrm{ca}$. $6 \%$ to $2 \%$ ). Sphaeoromorph acritarchs (i.e., Leiosphaeridia spp.) are still well represented in the Assemblage Zone 2, especially in bedded sandstones at $754.8 \mathrm{ft}$, where they represent about $82 \%$ of total palynomorph content.

The interval marks the introduction of the chitinozoan Siphonochitina formosa (index of the eponymous zone of middle Darriwilian age), and the first occurrence of Striatotheca, 


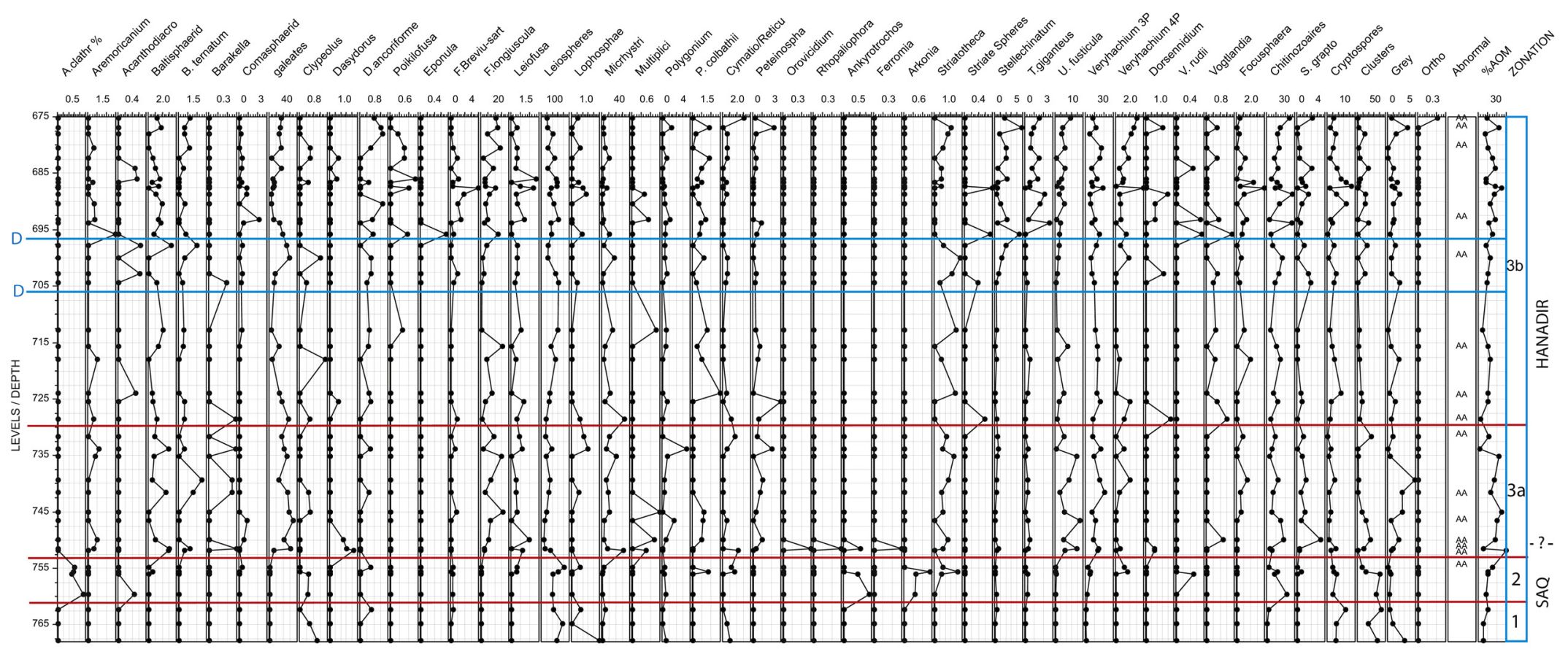

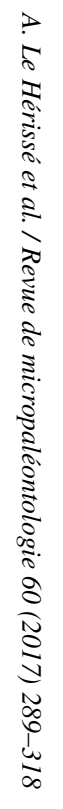

Fig. 4. Quantitative stratigraphical distribution in relative abundances of palynomorphs and amorphous organic matter between 767.8 and $675.1 \mathrm{ft}$ in the QSIM-801 well. 


\begin{tabular}{|c|c|c|c|c|c|c|}
\hline LEVELS & galeates & GALEATE F.longiusch & F.LONGIl Leiosphere & LEIOSPHI Micrhystri & MICRHYS Veryhachiu & VERYHAC Cryptospor \\
\hline 675.1 & 16,95 & 10,65 & 19,13 & 2,17 & 7,6 & 2,17 \\
\hline 676.8 & 15,53 & 11,97 & 21,35 & 1,6 & 11,00 & 0,97 \\
\hline 677.9 & 13,76 & 4,52 & 40,84 & 2,2 & 4,21 & 2,91 \\
\hline 680.4 & 16,71 & 13,82 & 22,76 & 4,3 & 17 & 2,00 \\
\hline 682.2 & 3,00 & 1,5 & 47,00 & 10,2 & 15,25 & 0,9 \\
\hline 684 & 17,07 & 8,78 & 22,19 & 0,73 & 6,34 & 3,41 \\
\hline 685.9 & 4,6 & 2,71 & 52,98 & 1,35 & 12,22 & 4,89 \\
\hline 686.5 & 6,6 & 2,64 & 56,25 & 0,00 & 6,25 & 6,73 \\
\hline 687.2 & 6,3 & 3,1 & 55,36 & 0,00 & 7,3 & 8,7 \\
\hline 687.5 & 4,78 & 10,35 & 34,6 & 6,77 & 18,7 & 0,8 \\
\hline 688.6 & 2,4 & 5,88 & 28,87 & 0,52 & 4,54 & 3,2 \\
\hline 690.3 & 2,54 & 3,2 & 44,26 & 0,00 & 5,2 & 6,8 \\
\hline 693.1 & 5,7 & 4,6 & 61,00 & 1,8 & 10,00 & 1,05 \\
\hline 693.7 & 14,5 & 2,2 & 33,48 & 0,44 & 6,6 & 1,76 \\
\hline 695.7 & 18,95 & 12,26 & 35,68 & 10,4 & 14,86 & 0,00 \\
\hline 697.7 & 24,67 & 3,94 & 23,35 & 2,3 & 11,5 & 2,3 \\
\hline 699.9 & 28,9 & 0,93 & 22,36 & 17,7 & 5,59 & 0,31 \\
\hline 702.7 & 7,96 & 1,9 & 50,63 & 1,59 & 6,68 & 3,1 \\
\hline 704.3 & 6,6 & 0,38 & 61,28 & 0,58 & 9,3 & 2,3 \\
\hline 712.7 & 2,34 & 0,26 & 58,59 & 15,1 & 10,41 & 0,78 \\
\hline 715.6 & 13,58 & 15,45 & 33,95 & 4,2 & 12,64 & 1,63 \\
\hline 717.9 & 3,7 & 3,95 & 50,1 & 2,2 & 13,08 & 2,46 \\
\hline 723.9 & 14.10 & 7,8 & 29.47 & 11,58 & 12,09 & 4,85 \\
\hline 725.4 & 17,84 & 3,00 & 26,93 & 4 & 15,8 & 1,3 \\
\hline 728.5 & 27,46 & 0,59 & 15,82 & 32,52 & 7,76 & 0,89 \\
\hline 731.6 & 17,54 & 9,21 & 14,00 & 10,52 & 7,45 & 0,00 \\
\hline 733.8 & 21,00 & 1,45 & 36,44 & 6,12 & 16,32 & 1,16 \\
\hline 735.11 & 25,19 & 14,72 & 16,27 & 20,54 & 8,91 & 0,38 \\
\hline 739.3 & 13,33 & 6,92 & 30 & 5,9 & 15,12 & 2,56 \\
\hline 741.5 & 26,22 & 2,82 & 25,7 & 8,74 & 20,56 & 0,51 \\
\hline 745 & 28,36 & 15,8 & 17,54 & 10,5 & 6,7 & 1,1 \\
\hline 746.5 & 34,34 & 6,64 & 11,08 & 3,04 & 10,52 & 0,55 \\
\hline 749.9 & 20,87 & 5,33 & 7,76 & 2,42 & 8,25 & 0,48 \\
\hline 751.5 & 30,44 & 2,2 & 11,94 & 7,76 & 14,02 & 2,98 \\
\hline 751.8 & 6,08 & 2,3 & 31,88 & 31,00 & 13,04 & 1,2 \\
\hline 754.8 & 0,3 & 0,00 & 81,85 & 2,4 & 2,4 & 1,84 \\
\hline 755.6 & 0,28 & 0,00 & 60,00 & 0,84 & 5,00 & 2,24 \\
\hline 756 & 0,25 & 0,00 & 40,85 & 0,25 & 4,5 & 3,25 \\
\hline 759.6 & 0,23 & 0,00 & 39,00 & 0,46 & 1,4 & 1,88 \\
\hline 762.3 & 0,00 & 0,00 & 42,95 & 4,59 & 0,32 & 6,55 \\
\hline 764.8 & 0,28 & 0,00 & 76,00 & 0,56 & 0,00 & 3,17 \\
\hline 767.8 & 0,00 & 0,00 & 55,00 & 0,5 & 0,5 & 3,00 \\
\hline
\end{tabular}

\footnotetext{
No representation

Very low \%

Low \%

Moderate \%

High \%

Very high \%
}

Fig. 5. Relative abundance of the main groups of acritarchs and the cryptospores in the QSIM-801 well. 
represented by $S$. rarirrugulata, $S$. monorugulata and $S$. mutua, this latter being entirely confined within the zone. Other notable FADs are those of Acanthodiacrodium costatum, Ampullula suetica (uncommon), Ankyrotrochos crispum, Micrhystridium regulum sp. nov., Pterospermopsis colbathii, Tyrannus proteus sp. nov., and Uncinisphaera fusticula. The top of the zone is marked by the Last Appearance Datums of Arkonia sp. A and Aureotesta clathrata. These disappearances at the top of Zone 2 might be controlled by local paleoenvironmental conditions, as these species are known to occur throughout the entire Darriwilian in other localities.

This assemblage zone is also characterized by the first stratigraphic occurrence of common minute acritarchs and sphaeromorphs of ultraplanktonic size range (5-15 $\mu \mathrm{m})$, which will become abundant in the succeeding Zone 3 .

The FAD of the distinctive species Tyrannus proteus (previously indicated as Tyrannus sp. A in Le Hérissé et al., 2007), is now well established at the top of core 8. Because of its distinctive morphology, the FAD of T. proteus holds considerable potential for correlation in other Saudi Arabian sections.

The present assemblage shares many similarities with previously described assemblages of Darriwilian (Middle Ordovician) age in worldwide localities. For example, Striatotheca monorugulata is considered to have a short stratigraphic range, which does not extends above the $D$. hirundo graptolite zone and equivalents e.g. the $U$. austrodentatus zone of South China (Yin et al., 1998), of early Darriwilian age. Other taxa such as Ankyrotrochos crispum or Pterospermopsis colbathii are not reported elsewhere in deposits older than the Darriwilian (Vecoli and Le Hérissé, 2004).

Some isolated occurrences of taxa which indicate a pre-Darriwilian age such as Caldariola glabra and Striatotheca monorugulata could resulting from sediment reworking from underlying strata. Reworking was also previously mentioned by Al-Hajri (1995, p. 33), who noted the possibility of extensive reworking of "Arenig"-aged (i.e., upper Dapingian) taxa from the Saq Formation into the "Llanvirn" (Darriwilian) Hanadir Member at the base of the Qasim Formation.

\subsubsection{Assemblage Zone 3}

Assemblage Zone 3 extends from $751.8 \mathrm{ft}$ (corresponding to the Saq/Hanadir boundary) up to the top of the cored section at $675.1 \mathrm{ft}$. Starting from the base of this Zone, samples proved very productive, and many FADs of stratigraphically important species are recorded, especially within two intervals; 751.8-731.6 ft (defining sub-Zone $3 \mathrm{~A}$ ) and 728.5-675.1 ft (defining sub-Zone 3B).

In Assemblage Zone 3, palynofacies analysis reveals a significant increase in relative proportion of AOMs, increasing from $15 \%$ of total organic content at $754.8 \mathrm{ft}$ (top of Zone 2), to $30 \%$ at $751.8 \mathrm{ft}$ (base of Zone 3). This sudden accumulation of organic matter, especially abundant in the lower part of the zone (i.e., sub-Zone 3A) could reflect either a deepening of the Hanadir depositional paleoenvironment, or a condensed horizon.

Based on the distribution of chitinozoans, Assemblage subZone $3 \mathrm{~A}$ correlates with the middle and upper part of the formosa chitinozoan Biozone. Assemblage sub-Zone 3B correlates with top of the formosa Biozone and to the pissotensis Biozone. The presence of these two chitinozoan index species constrains the age of Assemblage Zone 3 to the late-middle to late Darriwilian.

Sub-Zone 3A shows the progressive introduction of Aremoricanium rigaudae, Aremoricanium aff. A squarrosum, Baltisphaeridium klabavense, B. ternatum, Dasydorus cirritus, Peteinosphaeridium trifurcatum, Barakella fortunata, Striatotheca quieta, Vogtlandia ramificata, Focusphaera elongata, Barakella rara and Peteinosphaeridium velatum, among the most important species.

Focusphaera elongata has been previously described in the Middle Ordovician of the Solimões Basin, Benjamin Constant, Brazil by Quadros (1986a), in the local Arkonia virgata zone, dated to the Arenig-Llanvirn (Dapingian-Darriwilian; Quadros, 1988).

A significant change in distribution of chronostratigraphically valuable acritarchs occurs at the base of sub-Zone 3B (728.5 ft), with the First Appearance Datums of the following taxa: Poikilofusa ciliaris, Pterospermopsis franciniae, Vogtlandia tenuata, Aremoricanium aff. A. decoratum, Vogtlandia sp. A of Vecoli (1999), Glaucotesta latiramosa, Striatotheca principalis parva, Dactylofusa striatogranulata, Acanthodiacrodium uniforme, Striatotheca frequens, Frankea sartbernardensis, and Orthosphaeridium spp. This boundary between subzones $3 \mathrm{~A}$ and $3 \mathrm{~B}$ corresponds also to the LAD of Ankyrotrochos crispum.

Globally, Assemblage Zone 3 shows similarities with the Frankea sartbernardensis-Vogtlandia ramificata assemblages described from North Africa (Vecoli, 1999; Vecoli et al., 1999a, b), and with the JO-3 Zone defined in the subsurface of Jordan (Keegan et al., 1990), both of which are attributed to the mid to late Darriwilian. It is worth nothing that in the North African assemblages all the main species make their first inception from the base of the zone, while in QSIM-801, species first appear progressively through the section. This could reflect differing local paleoecological conditions, or could be explained by a major disconformity in the North African succession, where the Darriwilian Bir ben Tartar Formation directly overlies the Tremadocian Sanrhar Formation. However, no details were given about the order of appearance of taxa in the JO-3 Zone of Keegan et al. (1990).

Other assemblages which share many species with the present zone are those described by Gutierrez Marco et al. (1996) in the Darriwilian of Spain, and by Vavrdová (1982) in the Darriwilian Sarka Formation of the Bohemian Basin (e.g., occurrence of Glaucotesta latiramosa).

A peculiarity of the QSIM-801 section is the rarity of the typical Darriwilian acritarch Frankea sartbernardensis, a classical marker of the upper Arenig to Llanvirn (Darriwilian) in many worldwide localities (Vecoli and Le Hérissé, 2004). This might reflect a more general facies control on the biogeographic distribution of this species. Also, the presence of Pterospermopsis franciniae is notable in the present assemblage, because this is a distinctive species that has been so far only been described from the Darriwilian of Australia (Aremoricanium solaris and Dactylofusa striatogranulata Zones, Goldwyer and Tina formations; Quintavalle and Playford, 2006a, b). 


\subsection{Quantitative analysis and discussion}

Figs. 4 and 5 show the variations of relative abundances of acritarchs, freshwater algae, cryptospores, and of AOM in the QSIM-801 section. The distribution of palynomorphs and their changes in relative abundances are interpreted as reflecting paleoenvironmental changes throughout the studied section. The biostratigraphic constrains provided by the chitinozoans (i.e., presence of pissotensis and formosa biozones, middle to late Darriwilian) for the $28 \mathrm{~m}$ (93 ft) thick QSIM-801 section indicate that the studied section is very condensed, particularly when considering an estimated duration of the Darriwilian of ca. 9 Myr (Cohen et al., 2013). Comparable Middle Ordovician stratigraphic sections in the Armorican Massif of France, for example, consist of several hundred meters of strata (Dabard et al., 2015).

The most important taxonomic categories and species, that exhibit relatively high frequencies are: the galeate acritarchs (e.g., Stelliferidium and Cymatiogalea), Frankea longiuscula var. darriwilense, Leiosphaeridia spp., Micrhystridium spp., triangular Veryhachium, chitinozoans, cryptospores, and sphaeromorph clusters.

The successive introductions of the two chitinozoan species Siphonochitina formosa and Linochitina pissotensis respectively at 759.6 and $699.9 \mathrm{ft}$ (Fig. 4) correspond to transgressive events, and coincide with pulses of increased acritarch diversity (e.g., FADs of A. clathrata, Arkonia spp., etc.), along with a corresponding drop cryptospore abundance. The wide distribution of these events on the north Gondwanan margin and the Middle East (Paris, 1990, 1996), their amplitude and rapidity, have been considered as evidence for a glacio-eustatic origin (Dabard et al., 2015, p. 107).

The relative abundance of the terrestrially-derived cryptospores and Michystridium spp. are generally inversely proportional in the studied section (Fig. 4). An inverse relationship is also observed between abundances of leiospheres and Frankea longiuscula var. darriwilense. These features are especially evident in two intervals, at $754.8-767.8 \mathrm{ft}$ and 685.9-687.2 ft, where peaks in cryptospore abundance (up to $8.7 \%$ of total palynomorph content) seems to suggest restricted marine conditions. Here, the high abundance of cryptospores, clearly indicates nearby active fluvio-deltaic sources (Tyson, 1993).

Variations in abundance of Micrhystridium (Figs. 4 and 5) appear to be correlated to stratigraphic surfaces such as flooding surfaces, condensed surfaces such as lag deposits, or other diastems. At the Saq/Hanadir boundary, the relative abundance of Micrhystridium increases from $2.4 \%$ at $754.8 \mathrm{ft}$ (topmost Saq) to $31 \%$ at $751.8 \mathrm{ft}$ (lowermost Hanadir). A similar increase in abundance of Micrhystridium occurs between $731.6 \mathrm{ft}$ (ca. 10\%) and $728.5 \mathrm{ft}$ (ca. 32\%.), which also corresponds to the boundary between subzones $3 \mathrm{~A}$ and $3 \mathrm{~B}$. Both of these peaks in the abundance of Micrhystridium also correspond to maxima in acritarch diversity, and are considered to correlate to flooding surfaces.

A similar increase in the relative abundance of Micrhystridium is observed across a sedimentary discontinuity represented by a conglomeratic lag deposit at $697.5 \mathrm{ft}$ and interpreted as marking a transition from proximal to distal pro-delta facies. In this case, the Micrhystridium abundance increases from ca. $2 \%$ at $697.7 \mathrm{ft}$ to $10 \%$ at $695.7 \mathrm{ft}$, in parallel with a significant decrease in cryptospore abundance from $2.3 \%$ to almost zero, consistently with a change from proximal to distal conditions.

Triangular acritarch morphotypes such as Arkonia, Frankea, three-processed Veryhachium, and triangular morphotypes of Tyrannus proteus show a marked increase in relative abundance at the base of the Hanadir Member. Triangular Veryhachium reaches up to $30 \%$ of total palynomorph content in several samples. Previous work (Le Hérissé et al., 2007, p. 12) has suggested a correlation between high abundances of triangular Veryhachium and the onset of glacial conditions, based on analysis of glacial-related sediments in the Upper Ordovician of Morocco (Bourahrouh et al., 2004). This condition is seen as well in the Upper Devonian of Brazil (Le Hérissé, 2015).

In several levels in the Hanadir Member some acritarch species, such as Frankea longiuscula var. darriwilense, Dicrodiacrodium ancoriforme and Tyrannus proteus, display extreme polymorphism, leading, in some cases, to aberrant (teratological) morphotypes. Previous studies have correlated the occurrence of aberrant acritarch morphotypes to changes in paleoenvironmental parameters such as changes in salinity of oceanic waters (Ellegaard, 2000), $\delta^{13} \mathrm{C}$ excursions linked to glacial events (Munnecke et al., 2012), or high levels of heavy metals in the sediments (Vandenbroucke et al., 2013). Any of these parameters, alone or in combination, could be at play in the present material from the Hanadir Member in QSIM-801. However, the establishment of a causal relationship between the occurrence of aberrant forms, or extreme polymorphic species, and paleoecological conditions would require detailed geochemical analysis that is beyond the scope of the present study.

\subsection{Distribution and importance of minute palynomorphs}

The importance of small phytoplanktonic forms is well established in oceans today and they play crucial roles as primary producers, bacterial grazers and parasites (Barber and Hilting, 2002; Not, 2004). The scheme for classification of marine microorganisms according to size was delineated largely based on sieving technology. Sieburth et al. (1978) split microorganisms into three categories: microplankton (larger than $20 \mu \mathrm{m}$ ), nannoplankton (from 2 to $20 \mu \mathrm{m}$ ) and picoplankton (smaller than $2 \mu \mathrm{m}$ ). The term, ultraplankton, also used herein, added later by Murphy and Haugen (1985), is defined as the sum of picoplankton and nannoplankton. The size range of the minute palynomorphs observed in the QSIM-801 material generally belongs to the ultraplankton.

Minute palynomorphs have been detected in many palynological residues from Paleozoic rock samples, but they have not received attention because their small size makes taxonomical studies and biostratigraphic applications difficult. Moreover, conventional palynological preparations make use of sieves with mesh sizes around $15 \mu \mathrm{m}$, and many of these small palynomorphs are lost during sieving. According to Servais et al. (2016): "the fossil record of the phytoplankton is biased by a huge mesh-size effect and reports of fossil phytoplankton 


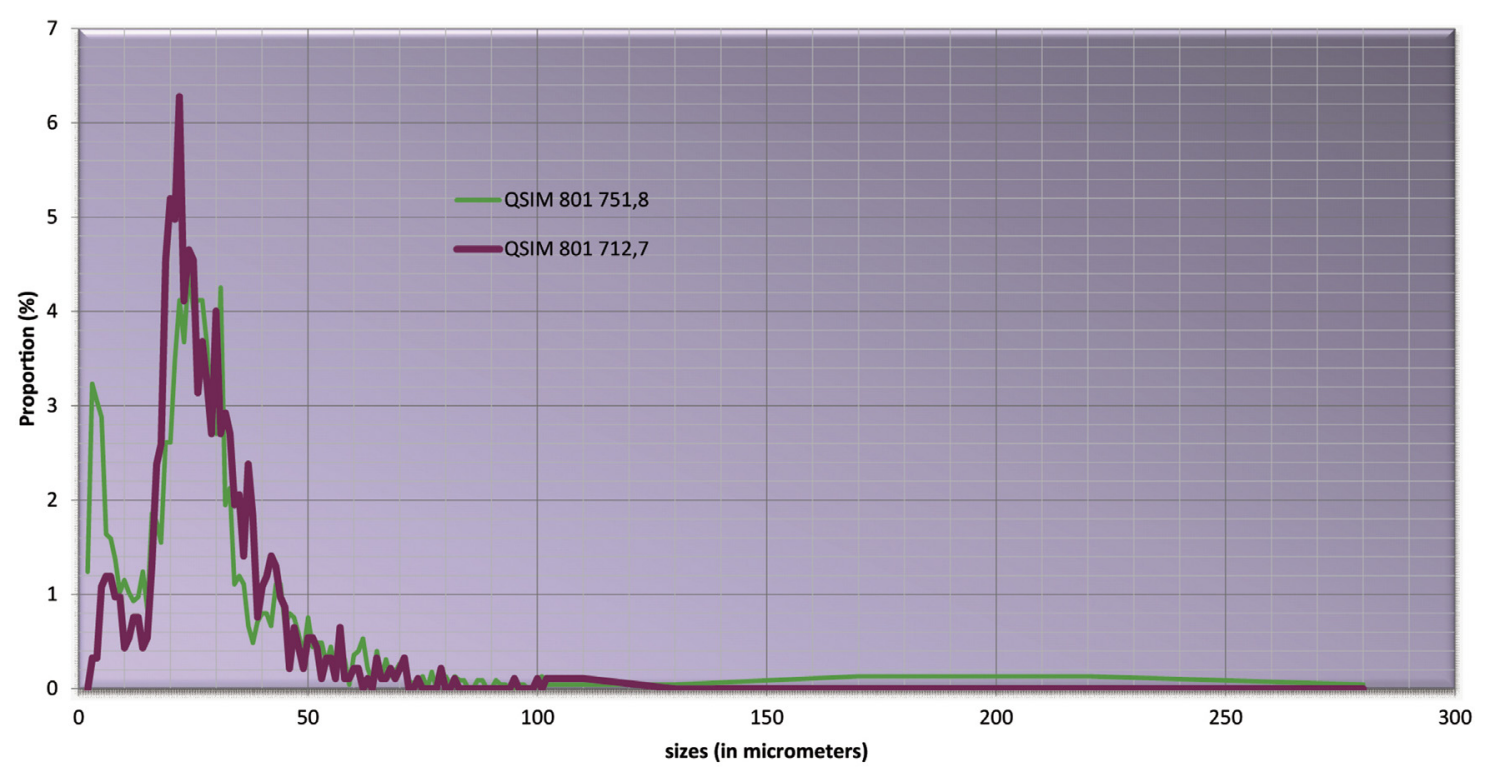

Fig. 6. Size distribution of palynomophs in the samples to 751.8 and $712.7 \mathrm{ft}$ in QSIM 801-well.

$<20 \mu \mathrm{m}-$ picoplankton and in particular of bacterioplankton - are virtually absent". However, small palynomorphs can reveal important paleoecological and paleoenvironmental information. For example, their high surface/volume ratio has been considered to convey a selective advantage in oligotrophic or reduced light conditions (Prauss, 2000). In order to categorize the abundant record of minute palynomorphs encountered in the QSIM-801 section, and attempt to understand their possible paleoecological significance, a size distribution analysis was performed.

Body-size trends of the acritarch and sphaeromorphic palynomorphs in QSIM-801 material

A simple approach has been used for the measurements of these microfossils, taking account of the total diameter, i.e., sum of central body diameter + length of ornamentation. The variations in body size of the palynomorphs in the study sections are well illustrated by the analysis performed on two samples (758 and $712.7 \mathrm{ft}$ ), which are considered representative of the entire studied section. A total of 2250 and 920 microfossils were counted in sample $758 \mathrm{ft}$ (core 7) and $712.7 \mathrm{ft}$ (core 4), respectively (Figs. 6 and 7). The counts were made on 5 palynological slides for each sample.

This quantitative analysis demonstrates that a wide range of body sizes are represented in the same sample. Three main size classes can be isolated. The first is represented by forms less than $10 \mu \mathrm{m}$ in diameter (ultraplankton), with abundances of 6 to $16 \%$ of the total palynomorph content. The second includes forms in the 10-20 $\mu \mathrm{m}$ size range (ultraplankton and microplankton), representing $c a .15 \%$ of all the microfossils. Finally, the majority of forms (70 to $79 \%$ of total palynomorphs) fall entirely in the microplankton size range (greater than $20 \mu \mathrm{m}$ ). The ultraplanktonic forms show two further peaks in size ranges: one between 4 and $6 \mu \mathrm{m}$ and another between 18 and $22 \mu \mathrm{m}$, while a group with mean sizes in the $12.5-14 \mu \mathrm{m}$ range is much less represented. The analysis of residue filtered with microporous filters

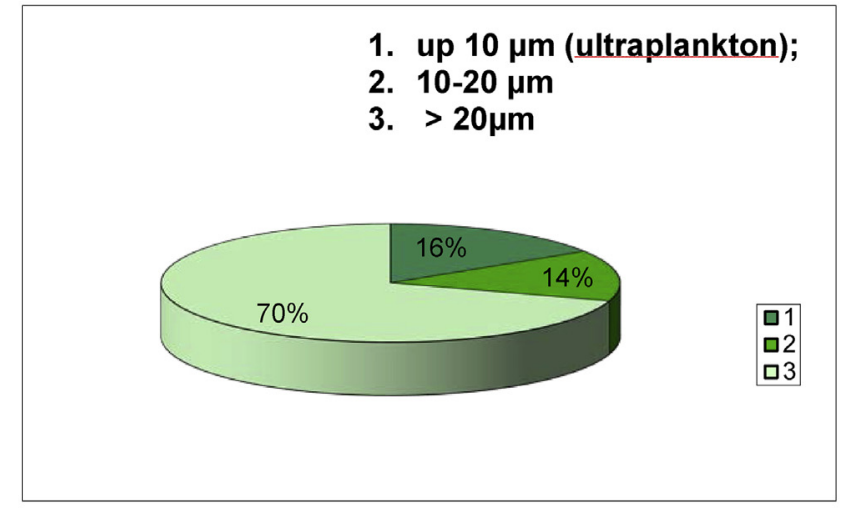

$751.8 \mathrm{ft}$.

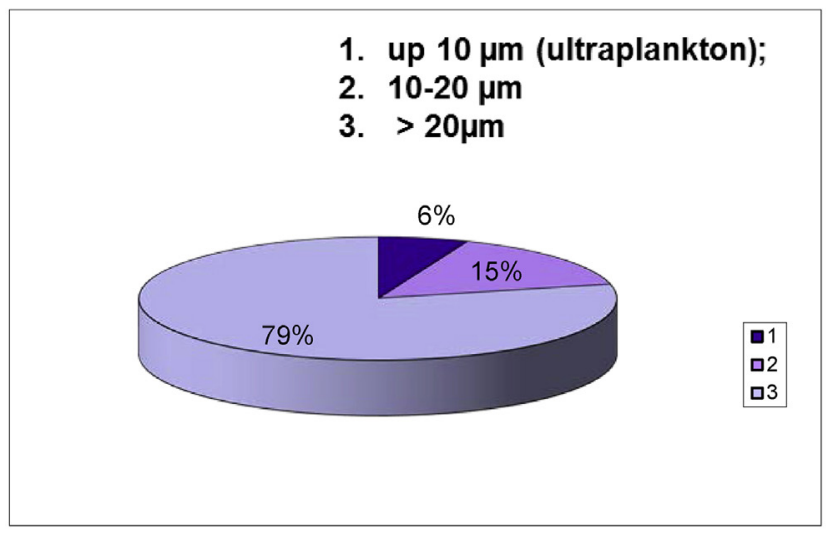

$712.7 \mathrm{ft}$.

Fig. 7. Pie charts of size distribution of the palynomorphs in samples to 751.8 and $712.7 \mathrm{ft}$ in QSIM-801 well.

with mesh sizes smaller than $5 \mu \mathrm{m}$, revealed the partial absence of small forms in the 1-4 $\mu \mathrm{m}$ size range, but an abundance of nannospheres smaller than $1 \mu \mathrm{m}$ in diameter. The nannospheres are the third category of minute palynomorphs discussed here. 


\section{Minute palynomorphs categories}

Based on morphological criteria, three main categories of minute palynomorphs can be distinguished in the present material: a) nannospheres, with a mean size less than $1 \mu \mathrm{m}$; b) acritarchs and small sphaeromorphs, with a total diameter between 5 and $20 \mu \mathrm{m}$; c) clusters of minute palynomorphs that are either interpreted as terrestrial spore masses, possible spores of chlorococcalean algae, clusters of small prasinophycean algae, or other microalgae, which are aggregates of small cells of 6 to $15-20 \mu \mathrm{m}$ in diameter.

\section{Nannospheres}

The nannospheres are the smallest elements identified in the present material, with a size between 0.2 to $1 \mu \mathrm{m}$. They have been extracted from water residues passed through 3 to $0.8 \mu \mathrm{m}$ Nucleopore Polycarbonate filters (Plate 7, Figs. 15, 16). In optical view nannospheres appear stained, possibly rich in sulfur, like the accumulations seen in modern freshwater deposits and illustrated by Lepot et al. (2014). They seem to be equivalent to the smallest $(<1 \mu \mathrm{m})$ nano-scale spheroids described from the Neoproterozoic black shales of the Ediacaran Doushantuo Formation in China (Borjigin et al., 2014). We suggest they are comparable to cell envelopes of cyanobacteria.

\section{Small acritarchs and sphaeromorphs}

Small acritarchs, including sphaeromorphs, are present throughout the section in significant proportions (Plate 7 , Figs. 5-10, 12). These small acritarchs, with diameters between 5 to $10 \mu \mathrm{m}$ belong to the ultraplankton category. Notable previous records of acritarchs belonging to this category are those from the Upper Vendian-Lower Cambrian of the East European Platform in Poland (e.g., Helosphaeridium radzynianum, 9-12 $\mu \mathrm{m}$ in overall diameter; Moczydlowska, 1991); from the early Cambrian of Estonia (Reticella corrugata, 4-10 $\mu \mathrm{m}$ in overall diameter with a porous wall structure; Agic, 2015); from the Silurian of Gotland, e.g., a small acanthomorph $5 \mu \mathrm{m}$ in diameter, hooked to a specimen of Eupoikilofusa rochesterensis illustrated by Le Hérissé (1989, Plate 13, fig. 7), and three specimens illustrated by Munnecke and Servais (1996; Plate 4, figs. 1, 2, 4) observed on polished and etched rock surfaces.

Notable Mesozoic and Cenozoic occurrence of small acritarchs and prasinophytes are from the Middle and Late Triassic (Roche, 1994; Brocke and Riegel, 1996; Feist-Burkhardt et al., 2008; Götz and Feist-Burkhardt, 2012; Riegel et al., 2014); Jurassic (Courtinat, 1983), Cretaceous (Habib and Knapp, 1982; Schrank, 2003); and Neogene (Head, 2003). Minute acritarchs do have some stratigraphic utility in the Cretaceous (Habib and Knapp, 1982), and the Neogene (de Vernal and Mudie, 1989; Head, 2003). Based on its distinctive morphology and short stratigraphic range in the QSIM-801 section, Micrhystridium regulum sp.nov., is considered as a potential useful biostratigraphical marker in the late-early to late Darriwilian of Saudi Arabia.

\section{Clusters of minute palynomorphs}

The last category of minute palynomorphs, but the second group in terms of abundance, consists of clusters and aggregates of sphaeromorphs. These elements, with cells of small size, between 5 and $25 \mu \mathrm{m}$ are particularly abundant in the Saq Formation (up to $40 \%$ of the palynomorph content) but are also recurrent and abundant in several levels also in the Hanadir Member.

Two main types can be distinguished. Type 1 clusters consist of smooth to ornamented, irregular and loosely packed units. Such clusters can be compared to forms described from the Proterozoic such as Symplassosphaeridium spp., or Synsphaeridium spp. (cf. e.g. Reidman et al., 2014, figs. G, H, S, P, U; Wellman and Strother, 2015, fig. 2, H.; Baludikay et al., 2016, fig. 12m). Many of these irregular clusters correspond to aggregates of small leiospheres that we consider to be prasinophyte. Specimens with pseudoreticulate ornamentation and small rounded openings (Plate 7, Fig. 19) recall the morphology of chlorococcalean (aplano)spores, such as those of Palambages morulosa illustrated by Tappan (1980, Fig. 10.25, p. 837).

Type 2 clusters consist of aggregates of densely packed, adherent units. These ones suggest possible analogies with cryptospore masses (e.g., Plate 7, Figs. 17, 18, 20) such as the fragments of sporangia illustrated by Wellman et al. (2003) from the Ordovician of Oman, but would need to be confirm by ultrastructure studies. In all cases, these closely adherent forms differ from the regular and planar cryptospore clusters described from the Middle Ordovician of Utah (Vecoli et al., 2015).

The occurrence of minute palynomorphs in the Middle Ordovician from Saudi Arabia, do not correspond to a drastic reduction in body size of the associated acritarchs and other palynomorphs, hence they cannot be attributed to the so-called "Lilliput Effect" (Urbanek, 1993). Likewise, the co-occurrence of large acritarch species such as Aremoricanium rigaudae or Tyrannus proteus with the minute palynomorphs, exclude a concentration effect of the latter by hydrodynamic sorting. It is important to recognize, after Riegel et al. (2014), that small acritarchs form a unique segment of microphytoplancton assemblages, which become abundant only in special environments and at certain stratigraphic levels. The present record of abundant minute acritarchs in the Middle Ordovician of Saudi Arabia is probably linked to adaptation to specific paleoenvironmental conditions (Fig. 2).

The abundance of small acanthomorphs (mostly Micrhystridium spp.) are variously interpreted in the literature. Schrank (2003) suggests an adaptation of the small acritarchs found in sands of the upper Cretaceous of Egypt to an interstitial (meiofaunal) mode of life. This relationship between acritarchs and coarse-grained littoral sediments was also noted by Courtinat (2000) and Sarjeant and Taylor (1999). However, as noted by Riegel et al. (2014), this proposed interstitial mode of life is not consistent with the occurrence of minute acritarchs and prasinophytes in oceanic clays and marls-including those of the Lower Cretaceous of the western North Atlantic (Habib and Knapp, 1982) and in limestones and marls of the Middle Triassic Jena Formation in Germany. According to Riegel et al. (2014), no single mode of life can be attributed to the small acritarchs. For their Triassic record, they proposed that changes in abundance of the minute acritarchs were essentially salinity controlled. In the present material, taking into account the high polymorphism of several species and the variation in terrestrial input (e.g. cryptospore abundance and clusters of possible cryptospores masses, etc.), the main changes in the abundance of 
minute palynomorphs seen here might be primarily controlled by changes in salinity.

\section{Conclusions}

Transitional strata between the Sajir Member of the Saq Formation and the Hanadir Member of the Qasim Formation cored by QSIM-801 well in Central Saudi Arabia contain profuse and well-preserved palynomorphs of terrestrial and marine origin; in this paper, the marine microplankton has been studied in detail, and three Assemblage Zones (1-3) have been defined, with Assemblage Zone 1 and 2 occurring in the Sajir Member and Assemblage Zone 3 occurring in the Hanadir Member. This analysis shows that the studied section is late-early to late Darriwilian in age on the basis of the presence of the formosa and pissotensis chitinozoan zones.

Three new species of acritarchs have been described: Frankea longiuscula var. darriwilense var. nov., Micrhystridium regulum sp. nov., and Tyrannus proteus sp. nov.

Detailed quantitative analysis of the relative abundance of major palynomorph groups and AOMs reveal high-frequency variations and abrupt changes in the distribution of marine and non-marine palynomorphs, which are most probably related to changes in paleoecological and depositional conditions. The analysis confirms also the importance of the triapsidate acritarchs and the frequency of abnormal (teratological) forms that could be correlated to environmental stress and possibly a glacial event.

The Sajir Member of the Saq Formation is characterized by predominance of terrestrial palynomorphs (cryptospores) and prasinophytes (e.g., Leiosphaeridia spp.) as well as clusters of small spaheromorphs, while acritarchs are relatively undiversified and chitinozoans poorly represented. The chitinozoan index species Siphonochitina formosa first occurs in Assemblage Zone 2 in the topmost Sajir Member, containing the biostratigraphic age to the late-early Darriwilian.

The transition between the Sajir Member of the Saq Formation and the Hanadir Member of the Qasim Formation is sharp in the QSIM-801 section. It is characterized by a marked increase in abundance and diversity of acritarchs and large quantities of AOMs, indicating a deepening of the depositional paleoenvironment. Based on the biostratigraphic analysis, the Hanadir Member in QSIM-801 is late-middle to late-darriwilian in age (Assemblage Zone 3, and upper part of formosa and the whole pissotensis chitinozoans zones).

The organic richness of samples, particularly in the Hanadir Shale Member, is related to mixed terrestrial organic productivity and marine aquatic organic productivity, and to the extension of anoxic conditions. These elements permitted an increase in the organic matter deposition and good TOC values.

The Frankea longiuscula var. darriwilense acme and its extreme polymorphism, associated to minute palynomorphs in relation with variations of terrigenous delivery (cryptospore signal), could be indicator of changing salinity during the Darriwilian.

The abundance of minute palynomorphs compared to other parts of the Paleozoic, may indicate a locally severe ecological effect of the environmental changes on the composition of palynomorph assemblages (controlled by salinity and/or climate-driven).

Although these results must be regarded as provisional, they suggest that high-resolution quantitative palynological studies can provide a valuable tool for the identification of eustatic signatures, but also for changing salinity in the Middle Ordovician. The present findings add significant support for recent studies that have argued for the presence of ice sheets since the Darriwilian (Middle Ordovician) in Gondwana.

\section{Disclosure of interest}

The authors declare that they have no competing interest.

\section{Acknowledgements}

We acknowledge the Saudi Arabian Ministry of Petroleum and Mineral Resources and the Saudi Arabian Oil Company (Saudi Aramco) for providing the material for study and permission to publish. This study is a contribution to the programme "Nano", granting by the Labex Mer of University of Brest and IUEM. We thank PIMM-DRX Imagery platform of University of Brest and Gérard Sinquin and Phillipe Elies for their assistance in the CLSM and SEM studies. We additionally thank Amalia Spina (University of Perugia), Paul Strother (Boston College) and Kaya Ertug (Saudi Aramco) for valuable comments that greatly improved the manuscript.

\section{Appendix 1.}

List of palynomorph and other fossil taxa mentioned in the text and listed in Fig. 3.

Group Acritarcha Evitt, 1963

Acanthodiacrodium costatum Burmann, 1968

Acanthodiacrodium uniforme Burmann, 1968

Ampullula suetica Righi, 1991

Ankyrotrochos crispum (Vavrdová) Vecoli, 1999

Aremoricanium rigaudae Deunff, 1955

Aremoricanium solaris Quintavalle and Playford, 2006a

Aremoricanium aff. A. squarrosum Loeblich and Mac Adam, 1971

Aremoricanium aff. A. decoratum Loeblich and Mac Adam, 1971

Aremoricanium sp. A

Arkonia sp. A in Vecoli (1999)

Aureotesta clathrata (Vavrdová) emend. Brocke et al., 1997

Baltisphaeridium kalbavense (Vavrdová) kjellström, 1971

Baltisphaeridium ternatum (Burmann) emend Rauscher, 1973

Barakella felix Cramer and Diez, 1977

Barakella fortunata Cramer and Diez, 1977

Barakella rara (Lu Li-chang) emend Tongiorgi et al., 1995

Caldariola glabra (Martin) Molyneux in Molyneux and Rushton, 1988

Carminella maplewoodensis Cramer, 1964

Claviticystis bulbis Habib and Knapp, 1982 
Comasphaeridium aff. C. piluliferum Playford and Martin, 1984

Comasphaeridium aff. C. pratulum Cramer and Diez, 1977

Comasphaeridium sp.

Conaticystis orbis Habib and Knapp, 1982

Cristallinium sp.

Cymatiogalea spp.

Dactylofusa striatogranulata Jardiné, Combaz, Magloire, Peniguel et Vachey, 1974

Dasydorus cirritus Playford and Martin, 1984

Dicrodiacrodium ancoriforme Burmann, 1968 emend. Servais et al., 1996

?Dorsennidium sp.

Eupoikilofusa rochesterensis Cramer, 1970

Genus Focusphaera Quadros, 1986

Focusphaera elongata Quadros, 1986

Genus Frankea (Burmann, 1970) Servais, 1993 emend

Frankea breviuscula Burmann, 1970

Helosphaeridium radzynianum Moczydlowska, 1991

Leiofusa spp.

Lusatia dendroidea Burmann, 1970

Lusatia heteromorpha Vavdrova, 1986

Frankea longiuscula Burmann, 1970

Frankea longiuscula var. darriwilense var. nov.

Frankea sartbernardensis (Martin) Colbath, 1986

Glaucotesta latiramosa Vavrdová, 1982

Lophosphaeridium sp.

Genus Micrhystridium Deflandre, 1937

Micrhystridium regulum sp. nov.

Micrhystridium spp.

Multiplicisphaeridium irregulare Staplin et al., 1965

Multiplicisphaeridium multipugiunculatum Cramer and

Diez, 1977

Orthosphaeridium sp.

Peteinosphaeridium trifurcatum (Eisenack, 1931 ex Eisenack, 1938) Eisenack, 1969

Peteinosphaeridium velatum Kjellström, 1971

Peteinosphaeridium cf. P. sp. A in Vecoli (1999)

Peteinosphaeridium sp. B

Pirea sp.

Poikilofusa ciliaris Vecoli, 1999

Poikilofusa spinata Staplin et al., 1965

Polygonium dentatum (Timofeev ex Konzalová-Mazancová)

Albani, 1989

?Pulvinosphaeridium sp. A

Reticella corrugata Agic, 2015

Rhopaliophora palmata (Combaz and Peniguel) emend Paly-

ford and Martin, 1984

Riculasphaera fissa Loeblich and Tappan, 1969

Stellechinatum celestum (Martin) Turner, 1984

Stelliferidium stelligerum (Górka) emend Deunff et al., 1974

Stelliferidium striatulum (Vavrdová) Deunff et al., 1974

Stelliferidium sp. A

Striatotheca frequens Burmann, 1970

Striatotheca monorugulata Yin et al., 1998

Striatotheca mutua Burmann, 1970

Striatotheca principalis parva Burmann, 1970
Striatotheca quieta (Martin) Rauscher, 1974

Striatotheca rarirrugulata (Cramer, Kanes, Diez and Christopher) Eisenack et al., 1976

Symplassosphaeridium spp.

Synsphaeridium spp.

Tabulimicrocystis tetragonis Habib and Knapp, 1982

Genus Tyrannus Wood and Tekbali, 1987

Tyrannus giganteus (Jardiné et al., 1974) Wood and Tkbali, 1987

Tyrannus proteus sp. nov.

Uncinisphaera fusticula Vecoli, 1999

Undeterminate sp. A

Verrucidium globosum Habib and Knapp, 1982

Veryhachium checkleyensis Dorning, 1981

Veryhachium lairdii (Deflandre) Deunff, 1959 ex Downie, 1959

Veryhachium trispinosum group

Vogtlandia ramificata Burmann, 1970

Vogtlandia tenuata Burmann, 1970

Vogtlandia sp. A in Vecoli, 1999

Chlorococcales

Palembages morulosa Wetzel, 1961

Prasinophycean algae

Cymatiosphaera spp.

Cymatiosphaeropsis rotundus Habib and Knapp, 1982

Pterospermopsis colbathii Vavrdová, 1990

Pterospermopsis franciniae Quintavalle and Playford, 2006a

Zygnematales

Genus Gelasinicysta Head, 1992

Algae and questionable algae

Clusters of sphaeromorphs

Clypeolus sp.

Striate sphaeromorphs

Virgatasporites rudii Combaz, 1967

Cyanobacteria

Bavlinella foveolata (Shepeleva, 1962) Vidal, 1976

Sphaerocongregus variabilis Moorman, 1974

Enigmatic forms

Dark-grey element, Type 1

Dark-grey element, Type 2

Chitinozoa

Belonechitina henryi Paris, 1981

Desmochitina bulla Taugourdeau \& Jekhowsky, 1960

Desmochitina ornensis Paris, 1981

Linochitina pissotensis Paris, 1981

Siphonochitina formosa Jenkins, 1967

Possible fungi

Genus Germinosphaera (Mikhailova, 1986) emend Butter-

field, Knoll and Swett, 1996

Genus Tappania Butterfield, 2005

Graptolites

Didymograptus artus Elles and Wood, 1901

Didymograptus cf. bifidus (Hall) Ruedemann, 1947

Didymograptus hirundo Salter, 1863

Didymograptus murchinsoni (Beck, 1839)

Didymograptus protobifidus Elles, 1933

Undulograptus austrodentatus (Harris and Keble, 1932) 


\section{Trace fossils \\ Cruziana sp. D’Orbigny, 1842 \\ Phycodes fusiforme Seilacher, 2000}

\section{References}

Agic, H., 2015. A new species of small acritarch with a porous wall structure from the Early Cambrian of Estonia and implications for the fossil record of eukaryotic picoplankton. Palynology 40 (3), 343-356.

Albani, R., Bagnoli, G., Ribecai, C., Raevskaya, E., 2007. Late Cambrian acritarch Lusatia: Taxonomy, palaeogeography and biostratigraphic implications. Acta Palaeontologica Polonica 52 (4), 809-818.

Al-Hajri, S., 1995. Biostratigraphy of the Ordovician chitinozoa of northwestern Saudi Arabia. Review of Palaeobotany and Palynology 89, 27-48.

Baludikay, B.K., Storme, J.-Y., François, C., Baudet, D., Javaux, E.J., 2016. A diverse and exquisitely preserved organic-walled microfossil assemblage from the Meso-Neoproterozoic Mbuji-Mayi Supergroup (Democratic Republic of Congo) and implications for Proterozoic biostratigraphy. Precambrian Research 281, 166-184.

Barber, R.T., Hilting, A.K., 2002. History of the study of plankton productivity. In: Williams, P.J., Thomas, D.N., Reynolds, C.S. (Eds.), Phytoplankton productivity-Carbon assimilation in marine and freshwater ecosystems. Blackwell Science, pp. 16-43.

Borjigin, T., Yin, L., Yuan, X., Zhou, C., Meng, F., Xie, X., Bao, F., 2014. Nanoscale spheroids and fossils from the Ediacaran Doushantuo Formation in China. The Open Paleontology Journal 5, 1-9.

Bourahrouh, A., Paris, F., Elaouad-Debbaj, Z., 2004. Biostratigraphy, biodiversity and palaeoenvironments of the chitinozoans and associated palynomorphs from the Upper Ordovician of the Central Anti-Atlas, Morocco. Review of Palaeobotany and Palynology 130, 17-40.

Brocke, R., Riegel, W., 1996. Phytoplankton responses to shoreline fluctuations in the Upper Muschelkalk (Middle Triassic) of Lower Saxony (Germany). Neueus Jahrburg für Geologie und Paläontologie. Abhandlungen 200, 53-73.

Brocke, R., Fatka, O., Molyneux, S.G., Servais, T., 1995. First appearance of selected Early Ordovician Acritarch taxa from peri-Gondwana. In: Coop, J.D., Droser, M.L., Finney, S.C. (Eds.), Ordovician Odyssey. The Pacific Section for Sedimentary Geology, 77. , pp. 473-476.

Burmann, G., 1970. Weitere organische Mikrofossilien aus dem unteren Ordovizium. Paläontologische Abhandlugen, Abteilung B 3 (3/4), 289-332.

Butterfield, N.J., 2009. Modes of pre-Ediacaran multicellularity. Precambrian Research 173, 201-211.

Butterfield, N.J., Knoll, A.H., Swett, K., 1994. Paleobiology of the Neoproterozoic Svanbergfjellet Formation, Spitsbergen. Fossils and Strata 34, 1-84.

Courtinat, B., 2000. La matière organique sédimentaire en environnement de dépôt marginal. Exemple de la plaine deltaïque hypersaline du Ladinien de la bordure est du Massif central. Géologie de La France, no 1, 2000., pp. $35-45$.

Cohen, K.M., Finney, S.M., Gibbard, P.L., Fan, J.-X., 2013. The ICS International Chronostratigraphic Chart. Episodes 36 (3), 199-204.

Colbath, G.K., 1986. The lower Paleozoic organic-walled phytoplankton ("acritarch") genus Frankea Burmann, 1970. Micropaleontology 32 (1), $72-73$.

Colbath, G.K., 1990. Palaeobiogeography of Middle Paleozoic organic-walled phytoplankton. In: Mc Kerrow, W.S., Scotese, C.R. (Eds.), Palaeozoic Palaeogeography and Biogeography. Geological Society, London, Memoirs, 12, pp. 207-213.

Courtinat, B., 1983. Evidence ou réalité chez le genre Micrhystridium. Un exemple par l'étude des quelques formes Jurassiques du Jura Français. Cahiers de Micropaléontologie 1, 1-32.

Cramer, F.H., Díez, M.D.C., 1977. Late Arenigian (Ordovician) acritarchs from Cis-Saharan Morocco. Micropaleontology 23 (3), 339-360.

Dabard, M.P., Loi, A., Paris, F., Ghienne, J.F., Pistis, M., Vidal, M., 2015. Sealevel curve for the Middle to early Late Ordovician in the Armorican Massif (western France): Icehouse third-order glacioeustatic cycles, Palaeogeography, Palaeoclimatology. Palaeoecology 436, 96-111.
De Vernal, A., Mudie, P.J., 1989. Pliocene and Pleistocene palynostratigraphy at ODP Sites 646 and 647, eastern and southern Labrador Sea. In: Srivastava S.P., Arthur, M., Clement, B., et, al. (Eds.), Proceedings of the Ocean Drilling Program, Scientific Results, 105. Ocean Drilling Program, College Station, Texas, pp. 401-402.

El-Khayal, A.A., Romano, M., 1988. A revision of the upper part of the Saq Formation and Hanadir Shales (Lower Ordovician) of Saudi Arabia. Geological magazine $125,161-174$.

Ellegaard, M., 2000. Variation in dinoflagellate cyst morphology under condition of changing salinity during the last 2000 years in the Limfjord, Denmark. Review of Palaeobotany and Palynology 109, 65-81.

Fatka, O., Molyneux, S.G., Servais, T., 1997. The Ordovician acritarch Frankea: some critical remarks. Geobios 30, 321-326.

Feist-Burkhardt, S., Pross, J., 1999. Morphological analysis and description of Middle Jurassic dinoflagellate cyst marker species using confocal laser scanning microscopy, digital optical microscopy and conventional light microscopy. Bulletin Centre Recherche Exploration Production. Elf Aquitaine 22 (1), 103-145.

Feist-Burkhardt, S., Götz, A., Ruckwied, K., Russell, J.W., 2008. Palynofacies patterns, acritarch diversity and stable isotope signatures in the Lower Muschelkalk (Middle Triassic) of N Switzerland: evidence of third-order cyclicity. Swiss Journal of Geosciences 101, 1-15.

Ghavidel-Syooki, M., Popov, L.E., Javier Alvaro, J., Ghobadi Pour, M. Tolmacheva, T.Y., Eshani, M.-H., 2014. Dapingian-Lower Darriwilian (Ordovician) stratigraphic gap in the Faraghan Mountains, Zagros Ranges, southeastern Iran. Bulletin of Geosciences 89 (4), 679-706.

Ghazwani, A.H., 2012. Investigation of source rock potential and micropaleontology of the Middle Ordovician Hanadir Member of the Qasim Formation. Northwestern Saudi Arabia.

Ghienne, J.-F., Le Heron, D.P., Moreau, J., Denis, M., Deynoux, M., 2007. The Late Ordovician glacial sedimentary system of the North Gonwana platform. In: Hambrey, M., Christoffersen, P., Glasser, N., Janssen, P., Hubbard, B., Siegert, M. (Eds.), Glacial Sedimentary Processes and Products. International Association of Sedimentologists, 39. Blackwell, Oxford, Special Publication, pp. 295-319.

Götz, A.E., Feist-Burkhardt, S., 2012. Phytoplankton associations of the Anisian Peri-Tethys Basin (Central Europe): Evidence of basin evolution and paleoenvironmental change. Palaeogeography, Palaeoclimatology, Palaeoecology 337-338, 151-158.

Gutiérrez-Marco, J.C., Albani, R., Aramburu, C., Arbizu, M., Babin, C., GarciaRamos, C., Mendez-Bedia, I., Rabano, I., Truyols, J., Vannier, J., Villas, E., 1996. Bioestratigrafía de la Formación Pizzaras del Sueve (Ordovícico Medio) en el sector septentrional de la escama de Laviana-Sueve (Zona Cantábrica, Norte de España). Revista Espanola Paleontologia 11 (1), 48-74.

Gutiérrez-Marco, J.C., Sá, A.A., García-Bellido, D.C., Rábano, I., 2013. The extent of the Middle Ordovician Dapingian Stage in peri-Gondwanan Europe and north Africa: stratigraphic record, biostratigraphic tools and regional chronostratigraphy, GFF., pp. 1-5, 10.1080/11035897.2013.865667.

Gutiérrez-Marco, J.C., Sá, A.A., García-Bellido, D.C., Rábano, I., 2016. The Bohemo-Iberian regional chronosratigraphical scale for the Ordovician System and paleontological correlations within South Gondwana, Lethaia., http://dx.doi.org/10.1111/let.12197.

Habib, D., Knapp, S.D., 1982. Stratigraphic utility of Cretaceous small acritarchs. Micropaleontology 28 (4), 335-371.

Haq, B.U., Al-Qahtani, A.M., 2005. Phanerozoic cycles of sea-level change on the Arabian Platform. GeoArabia 10 (2), 127-160.

Head, M.J., 1992. Zygospores of the Zygnemataceae (Division Chlorophyta) and other freshwater algal spores from the uppermost Pliocene St Erth Beds of Corwall, southwestern England. Micropaleontology 38 (3), 237-260.

Head, M.J., 2003. Neogene occurrences of the marine acritarch genus Nannobarbophora Habib and Knapp, 1982 emend., and the new species N. Gedlii. Journal of Paleontology 77 (2), 382-385.

Helal, A.H., 1964. On the occurrence of Lower Paleozoic rocks in Tabuk area, Saudi Arabia. Neues Jahrbuch für Geologie und Paläontologie-Monatshefte 7, 391-415.

Ji, L.M., Meng, F.W., Schiffbauer, J.D., Xu, J.L., Yan, K., Shu, J.W., 2008. Correlation between highly abundant oil-prone Leiosphaerid acritarchs and 
hydrocarbon source rocks from the Triassic Yanchang Formation, eastern Gansu Province, Northwestern China. Gondwana Research 14, 554-560.

Keegan, J.B., Rasul, S.M., Shaheen, Y., 1990. Palynostratigraphy of the Lower Palaeozoic, Cambrian to Silurian sediments of the Hashemite Kingdom of Jordan. Review of Palaeobotany and Palynology 66, 167-180.

Khalifa, M.A., 1993. Anz Formation: a new Lower Ordovician rock unit, southwest of Al Qasim Province, Saudi Arabia. Egyptian Journal of Geology 37, 53-67.

Khalifa, M.A., 2015. The Ediacaran-Cambrian and Ordovician rocks of Al Qasim Province, Saudi Arabia: facies, depositional history and regional correlation. Journal of African Earth Sciences 109, 263-282.

Le Hérissé, A., 1989. Acritarches et kystes d'algues Prasinophycées du Silurien de Gotland, Suède. Palaeontographia Italica 76, 57-302.

Le Hérissé, A., Al-Ruwaili, M., Miller, M., Vecoli, M., 2007. Environmental changes reflected by palynomorphs in the early Middle Ordovician Hanadir Member of the Qasim Formation, Saudi Arabia. Revue de Micropaléontologie $50,3-16$.

Le Hérissé, 2015. Ordovician-Devonian acritarch and prasinophyte biostratigraphy of northern and northeastern Brazil. Petrobras project: "Palinologia das Bacias Paleozoicas do Norte do Brasil e Adjacências". Internal Report, $398 \mathrm{p}$.

Lepot, K., Compère, P., Gérard, E., Namsaraev, Z., Verleyen, E., Tavernier, I., Hodgson, D.A., Vyverman, W., Gilbert, B., Wilmotte, A., Javaux, E.J., 2014. Organic and mineral imprints in fossil photosynthetic mats of an East Antarctic Lake. Geobiology 12, 424-450.

Li, J., Servais, T., Yan, K., 2010. Acritarch biostratigraphy of the Lower-Middle Ordovician boundary (Dapingian) to the Global Stratotype Section and Point (GSSP) Huanghuachang, South China. Newsletter on Stratigraphy 43/3, 235-250.

Melvin, J., 2015. Lithostratigraphy and depositional history of Upper Ordovician and lowermost Silurian sediments recovered from the Qusaiba-1 shallow core hole. Qasim region, central Saudi Arabia. Review of Palaeobotany and Palynology 212, 3-21.

Moczydlowska, M., 1991. Acritarch biostratigraphy of the Lower Cambrian and the Precambrian-Cambrian boundary in southeastern Poland. Fossils and strata $29,1-127$.

Molyneux, S.G., Mohiuddin, U., Penney, R., Paris, F., 2002. Turnover of acritarchs and chitinozoan species, endemism and sequence stratigraphy in the Lower Palaeozoic of Oman. Polen 14, 132-133.

Molyneux, S.G., Osterloff, P., Penny, R., Spaak, P., 2006. Biostratigraphy of the Lower Paleozoic Haima Supergroup, Oman: its application in sequence stratigraphy and hydrocarbon exploration. GeoArabia 11, 17-48.

Molyneux, S.G., Delabroye, A., Wicander, R., Servais, T., 2013. Biogeography of early to mid Palaeozoic (Cambrian-Devonian) marine phytoplankton. In: Harper, D.A.T., Servais, T. (Eds.), Early Palaeozoic Biogeography and Palaeogeography. Geological Society, London, Memoirs, 38, pp. 365-397.

Mudie, P.J., 1992. Circum-arctic Quaternary and Neogene marine palynofloras: paleoecology and statistical analysis. In: Head, M.J., Wrenn, J.H. (Eds.), Neogene and Quaternary Dinoflagellate Cysts and Acritarchs. American Association of Stratigraphic Palynology Foundation, College Station TX, pp. 347-390.

Munnecke, A., Servais, T., 1996. Scanning Electron Microscopy of polished, slightly etched rock surfaces: a method to observe palynomorphs in situ. Palynology 20, 163-176.

Munnecke, A., Delabroye, A., Servais, T., Vandenbroucke, T.A., Vecoli, M., 2012. Systematic occurrences of malformed (teratological) acritarchs in the run-up of Early Palaeozoic $\delta{ }^{13} \mathrm{C}$ isotope excursions. Palaeogeography, Palaeoclimatology, Palaeoecology 367-368, 137-146.

Murphy, L.S., Haugen, E.M., 1985. The distribution and abundance of phototrophic ultraplankton in the North Atlantic. Limnology Oceanography 30, $47-58$.

Murthy, S., Kavali, P.S., Bernardes-de-Oliveira, M.E.C., 2015. Latest Permian palynomorphs from Jharia Coalfield, Damodar Basin, India and their potential for biostratigraphic correlation. Revue de Micropaléontologie 58, $167-184$.

Not, F., 2004. Structure et diversité des communautés de picoeucaryotes en milieu marin. Biodiversité et écologie. PhD, Paris VI., pp. 1-160, http://hal.upmc.fr/tel-01111001.
Paris, F., Boumendjel, K., Dabard, M.P., Ghienne, J.F., Loi, A., Videt, B., Achab, A., 2007. Chitinozoan-based calibration of early-mid Ordovician transgressive events on northern Gondwana. Acta Palaeontologica Sinica 46, 370-375.

Pawley, J.B., 2006. Handbook of biological confocal microscopy. Springer, New York, 985 p.

Playford, G., Martin, F., 1984. Ordovician acritarchs from the Canning Basin, Western Australia. Alcheringa 8, 187-223.

Pohl, A., Donnadieu, G., Le Hir, J.F., Buoncristiani, J.F., Vennin, E., 2014. Effect of the Ordovician paleogeography on the (in)stability of the climate. Climate of the Past 10, 2053-2066.

Pohl, A., Donnadieu, Y., Le Hir, G., Ladant, J.B., Dumas, C., AlvarezSolas, J., Vandenbroucke, T.R.A., 2016. Glacial onset predated Late Ordovician climate cooling. Paleoceanography 31, 1-22, http://dx.doi.org/10.1002/2016PA002928.

Powers, R.W., 1968. Lexique Stratigraphique International, III, Asie, fasc. 10 b 1, Arabie Saoudite. CNRS, Paris.

Powers, R.W., Ramirez, L.F., Redmond, C.D., Elberg Jr., E.L., 1966. Geology of the Arabian Peninsula-Sedimentary Geology of Saudi Arabia: US Geological Survey Professional Paper, 560-D. Washington.

Prauss, M., 2000. The oceanographic and climatic interpretation of marine palynomorph phytoplankton distribution from Mesozoic, Cenozoic and Recent sections. Göttinger Arbeit für Geologie. Paläontologie 76.

Prebble, J.G., Hannah, M.J., Barrett, P.J., 2006. Changing Oligocene climate recorded by palynomorphs from two glacio-eustatic sedimentary cycles, Cape Roberts Project, Victoria Land Basin, Antarctica. Palaeogeography, Palaeoclimatology, Palaeoecology 231, 58-70.

Quadros, L.P., 1986a. Ocorrência de microfósseis (Acritarchae) ordovicianos na Sub-bacia do Alto Amazonas, Brasil. Boletim Técnico da Petrobras 29 (3), 181-191.

Quadros, L.P., 1986b. Ocorrência de microfósseis (Acritarchae) ordovicianos na Sub-bacia do Alto Amazonas, Brasil. In: $4^{\circ}$ Congreso Argentino de Paleontología y Bioestratigrafía. Mendoza, Asociación Paleontológica Argentina/Conicet. Actas 1, 151-156.

Quadros, L.P., 1988. Zoneamento bioestratigráfico do Paleozóico Inferior e Médio (seção marinha) da Bacia do Solimões. Boletim de Geociências da Petrobras 2 (1), 95-109.

Quintavalle, M., Playford, G., 2006a. Palynostratigraphy of Ordovician strata, Canning Basin, Western Australia. Part One: acritarchs and prasinophytes. Palaeontographica, B 275, 1-88.

Quintavalle, M., Playford, G., 2006b. Palynostratigraphy of Ordovician strata, Canning Basin, Western Australia. Part Two: chitinozoans and biostratigraphy. Palaeontographica, B 275, 89-131.

Raiswell, R., Berner, R.A., 1986. Pyrite and organic matter in Phanerozoic normal marine shales. Geochemica et Cosmochimica Acta 50, 1967-1976.

Rasmussen, C.M.Ø., Ullmann, C.V., Jakobsen, K.G., Lindskog, A., Hansen, J., Hansen, T., Eriksson, M.E., Dronov, A., Frei, R., Korte, C., Nielsen, A., Harper, D.A.T., 2016. Onset of main Phanerozoic marine radiation sparked by emerging Mid Ordovician icehouse. Nature, Scientific Reports 6, http://dx.doi.org/10.1038/srep 18884 (Article number 18884).

Rickards, B.R., Booth, G.A., Paris, F., Heward, A.P., 2010. Marine flooding events of the Early and Middle Ordovician of Oman and the United Arab Emirates and their graptolite acritarch and chitinozoan associations. GeoArabia 15 (4), 81-120.

Riedman, L.A., Porter, S.M., Halverson, G.P., Hurtgen, M.T., Junium, C.K., 2014. Organic-walled microfossil assemblages from glacial and interglacial Neoproterozoic units of Australia and Svalbard. Geology, http://dx.doi.org/10.1130/G35901.1.

Riegel, W., Wiese, F., Arp, G., Wilde, V., 2014. Microphytoplankton from the Jena Formation (Lower Muschelkalk Subgroup, Anisian) in the forestry quarry at Herberhausen near Göttingen (Germany). In: Wiese, F., Reich, M., Arp, G. (Eds.), Spongy, slimy, cosy and more...". Göttingen Contributions to Geosciences, 77. , pp. 63-76.

Roche, M., (PhD Thesis, unpublished) 1994. Palynologie et palynofacies du Rhétien (Trias supérieur) du nord-est du Bassin de Paris. Université de Liège.

Sarjeant, W.A.S., Taylor, F.J.R., 1999. Dinoflagellates, fossil and modern: certain unresolved problems. Grana 38, 186-192. 
Schrank, E., 2003. Small acritarchs from the Upper Cretaceous: taxonomy, biological affinities and paleoecology. Review of Palaeobotany and Palynology $123,199-235$.

Scott, A.C., 1989. Observations on the nature and origin of fusain. International Journal of Coal Geology 12, 443-475.

Scott, A.C., 2010. Charcoal recognition, taphonomy and uses in palaeoenvironmental analysis. Palaeogeography Palaeoclimatology Palaeoecology 291, 11-39.

Seilacher, A., 2000. Ordovician and Silurian arthrophycid ichnostratigraphy. In: Sola, M.A., Worsley, D. (Eds.), Geological Exploration in Murzuk Basin, Amsterdam. Elsevier, pp. 237-258.

Senalp, M., Al-Duaiji, A.A., 2001. Qasim Formation: Ordovician Storm-and Tide-Dominated Shallow-Marine Siliciclastic Sequences, Central Saudi Arabia. GeoArabia 6 (2), 233-268.

Servais, T., 1993. The Ordovician acritarch Frankea. In: Molyneux, S.G., Dorning, K.J. (Eds.), Contributions to acritarch and chitinozoan research. Special Papers in Palaeontology, 47. , pp. 395-414.

Servais, T., 1997. The Ordovician Arkonia-Striatotheca acritarch plexus. Review of Palaeobotany and Palynology 98, 47-79.

Servais, T., Molyneux, S.G., 1997. The messaoudensis-trifidum acritarch assemblage (Ordovician: late Tremadoc-early Arenig) from subsurface of Rügen (Baltic Sea, NE Germany). Palaeontographia italica 84, 113-121.

Servais, T., Brocke, R., Fatka, O., 1996. Variability in the Ordovician acritarch Dicrodiacrodium. Palaeontology 39, part 2, 389-405.

Servais, T., Martin, R.E., Nützel, A., 2016. The impact of the «terrestrialisation process » in the late Paleozoic $\mathrm{PCO}_{2}, \mathrm{PO}_{2}$, and the "phytoplankton blackout". Review of Palaeobotany and Palynology 224, 26-37.

Sharland, P.R., Archer, R., Casey, D.M., Davies, R.B., Hall, A., Heward, A., Horbury, A., Simmons, M.D., 2001. Arabian Plate Sequence Stratigraphy. GeoArabia Special Publication SP2. Gulf PetroLink, Barhain, 371 p.

Sieburth, J. McN., Smetacek, V., Lenz, J., 1978. Pelagic ecosystem structure: heterotrophic compartments of the plankton and their relationship to plankton size fractions. Limnology Oceanography 23, 1256-1263.

Soufiane, A., Achab, A., 1993. Quelques assemblages de chitinozoaires de l'Ordovicien du Maroc, Bassin de Tadla. Geobios 26 (5), 535-553.

Steemans, P., Wellman, C.H., Gerienne, P., Le Hérissé, A., Vecoli, M., 2017. Middle Ordovician cryptospores from the Saq/Hanadir transitional beds in the Qsim-801 well, Saudi Arabia. Revue de Micropaleontologie (Special volume).

Steinecke, M., Bramkamp, R.A., Sanders, N.J., 1958. Stratigraphic relations of Arabian Jurassic Oil. In: Weeks, L.G. (Ed.), Habitat of Oil, the American Association of Petroleum Geologist, Tulsa. Oklahoma, USA, pp. 1294-1329.

Strother, P.K., Al-Hajri, S., Traverse, A., 1996. New evidence for land plants from the lower Middle Ordovician of Saudi Arabia. Geology 24, 55-58.

Strother, P.K., Traverse, A., Vecoli, M., 2015. Cryptospores from the Hanadir Shale Member of the Qasim Formation, Ordovician (Darriwilian) of Saudi Arabia: taxonomy and systematics. Review of Palaeobotany and Palynology 212, 97-110.

Stump, T.E., 1995. Geology and biostratigraphy of the Late Precambrian through Paleoezoic sediments of Saudi Arabia. Review of Palaeobotany and Palynology $89,5-17$.

Tappan, H., 1980. The Paleobiology of Plant Protists. W.H. Freeman, San Francisco, 1028 p.

Thompson, C.K., 2011. Carbon and sulfur cycling in Early Paleozoic Oceans. PhD thesis, University of Tennessee http://trace.tennessee. edu/utk_gradiss/1033.

Tongiorgi, M., Yin, L.-M., Di Milia, 1995. Arenigian acritarchs from the Daping section (Yangtze Gorges area, Hubei Province, Southern China) and their palaeogeographic significance. Review of Palaeobotany and Palynology 86, $13-48$.

Tyson, R.V., 1993. Palynofacies analysis. In: Jenkins, D.G. (Ed.), Applied Micropaleontology. Kluwer Academic Publishers, Dordrecht, pp. 153-193.
Trotter, J.A., Williams, I.S., Barnes, C.R., Lécuyer, C., Nicoll, R.S., 2008. Did cooling oceans trigger Ordovician biodiversification? Evidence from conodont thermometry. Science 321, 550-554.

Turner, B.R., Armstrong, H.A., Wilson, C.R., Makhlouf, I.M., 2012. High frequency eustatic sea-level changes during the Middle to early Late Ordovician of southern Jordan: Indirect evidence for a Darriwilian Ice Age in Gondwana. Sedimentary Geology 251-252, 34-48.

Urbanek, A., 1993. Biotic crisis in the history of the Upper Silurian graptolites. A palaeobiologic model. Historical Biology 7, 29-50.

Vandenbroucke, T.R.A., Armstrong, H.A., Williams, M., Paris, F., Zalasiewicz, J.A., Sabbe, K., Nõlvak, J., Challands, T.J., Verniers, J., Servais, T., 2010a. Polar front shift and atmospheric $\mathrm{CO}_{2}$ during the glacial maximum of the Early Paleozoic Icehouse. PNAS 107 (34), 14983-14986.

Vandenbroucke, T.R.A., Armstrong, H.A., Williams, M., Paris, F., Sabbe, K. Zalasiewicz, J.A., Nõlvak, J., Verniers, J., 2010b. Epipelagic chitinozoan biotopes map a steep latitudinal temperature gradient for earliest Late Ordovician seas: Implications for a cooling Late Ordovician climate. Palaeogeography, Palaeoclimatology, Palaeoecology 294, 202-219.

Vandenbroucke, T.R.A., Armstrong, H.A., Williams, M., Paris, F., Sabbe, K. Zalasiewicz, J.A., 2013. Chapter 24. Late Ordovician zooplankton maps and the climate of the Early Palaeozoic icehouse. Geological Society of London, Memoirs 38, 399-405.

Vaslet, D., 1990. Le Paléozoïque (Anté-Permien supérieur) d'Arabie Saoudite. Documents du B.R.G.M. 191, 1-230.

Vaslet, D., Berthiaux, A., Le Strat, P., Kellog, K.S., Vincent, P.L., 1987. Geological map of the Baqa quadrangle, sheet 27F, Kingdom of Saudi Arabia. Saudi Arabian D.M.M.R., Geoscience map GM-116A.

Vavrdová, M., 1982. Phytoplancton communities of Cambrian and Ordovician age of Central Bohemia. Vëstník Ústřédniho ústavu geologického 57 (3), $145-155$

Vecoli, M., 1999. Cambro-Ordovician palynostratigraphy (acritarchs and prasinophytes) of the Hassi-R'Mel area and northern Rhadames Basin, North Africa. Palaeontographia Italica 86, 1-112.

Vecoli, M., Le Hérissé, A., 2004. Biostratigraphy, taxonomic diversity and patterns of morphological evolution of Ordovician acritarchs (organic-walled microphytoplankton) from the northern Gondwana margin in relation to palaeoclimatic and palaeogeographic changes. Earth-Science Reviews 67, 267-311.

Vecoli, M., Beck, J.H., Strother, P.K., 2015. Palynology of the Ordovician Kanosh Shale at Fossil Mountain, Utah. Journal of Paleontology 89 (3), 424-447.

Vecoli, M., Tongiorgi, M., Playford, G., 1999a. The Ordovician acritarchs Frankea breviuscula, F. longiuscula, and F. sartbernardensis: a new study. Bollettino della Società Paleontologica Italiana 38 (2-3), 343-358.

Vecoli, M., Tongiorgi, M., Abdesselam-Roughi, F., Benzarti, R., Massa, D., 1999b. Palynostratigraphy of Upper Cambrian-Upper Ordovician intracratonic clastic sequences, North Africa. Bollettino della Società Paleontologica Italiana 38 (2-3), 331-341.

Webby, B.D., Paris, F., Droser, M.L., Percival, I.G., 2004. The Great Ordovician Biodiversification Event. Columbia University Press, New York.

Wellman, C.H., Strother, P.K., 2015. The terrestrial biota prior to the origin of land plants (embryophytes): a review of the evidence. Palaeontology 58 (4), 601-627.

Wellman, C.H., Osterloff, P.L., Mohluddin, U., 2003. Fragments of the earliest plants. Nature 425, 282-284.

Wood, G.D., Tekbali, A.O., 1987. A unique new genus of Acritarcha (organicwalled microphytoplankton) from the Tanezzuft Formation (Silurian) of Libya. Palynology 11, 107-112.

Yin, L.M., Di Milia, A., Tongiorgi, M., 1998. New and emended acritarch taxa from the lower Dawan Formation (Lower Arenig, Huanghuachang section, South China). Review of Palaeobotany and Palynolology 102, 223-248.

Zalasiewicz, J.A., Taylor, L., Rushton, A., Loydell, D.K., Rickards, R.B., Williams, M., 2009. Graptolites in British Stratigraphy. Geological Magazine 146 (2008), 785-850. 